\title{
Sídelní struktury doby bronzové v oblasti Vyškovské brány
}

\section{Bronze Age settlement patterns in the vicinity of the Vyškov Gate}

\section{David Parma / Zuzana Holubová / Klára Rybářová}

\begin{abstract}
Abstrakt
Nová data získaná velkoplošnými záchrannými archeologickými výzkumy nejsou často v souladu s dřive formulovanými představami o podobě sídelní sítě mladšího pravěku. Na př́kladu konkrétního regionu s dobrou datovou základnou jsou ukázány radikální změny sídelní sítě ve staré sídelní oblasti v průběhu doby bronzové a halštatské a zvažovány možné interpretace. Zohledněna je struktura pramenů, možné proměny subsistenčních strategií i společenského uspořádání, i vliv různých procesů nadregionálního významu.
\end{abstract}

\section{Klíčová slova}

doba bronzová, sídelní struktury, hradiště, záchranné výzkumy, Morava

\begin{abstract}
New data obtained by large-scale archaeological rescue excavations are often not in accordance with earlier formulated ideas of the appearance of the settlement network in later prehistory. The example of a particular region with good material base illustrates radical changes of the settlement network in the old settlement area during the Bronze Age and the Hallstatt Period, and offers some interpretations to be discussed. Attention is paid to the structure of sources, possible alterations of subsistence strategies and social structure, as well as to the effect of various processes of transregional importance.
\end{abstract}

\section{Keywords}

Bronze Age, settlement patterns, hillforts, rescue excavations, Moravia

Práce vznikla s podporou grantového projektu GAČR 14-33170P „Archeologie střední a mladší doby bronzové kontext a informační potenciál rozsáhlých záchranných výzkumü". 


\section{1. Úvod}

Archeologické výzkumy v trase dálnic přinášejí velká množství nových archeologických dat a umožňují postavit naše představy o struktuře pravěkého osídlení na novou úroveň. Je zřejmé, že pokrytí krajiny sídelními areály není jednoduše homogenní a rovnoměrné, naopak v jednotlivých obdobích byly preferovány pouze některé konkrétní polohy či širší oblasti. Dlouhodobá kontinuita či rychlé přesuny sídelních areálů, hustota osídlení, vazba na půdy a vodní zdroje, prrítomnost centrálních lokalit a jejich vliv na sídelní sít, to vše představuje klíčové zdroje informací o pravěkých společnostech. Na tomto místě je využito několika sad dat o lokalitách doby bronzové v regionu Vyškovské brány ke sledování rozsahu a rychlosti proměn sídelní sítě, a to především v intervalu od střední doby bronzové do doby halštatské (údaje o osídlení starší doby bronzové dosud nebyly kompletně revidovány).

Standardní syntetické práce představují osídlení Moravy a Slezska v době bronzové na širší úrovni regionu o rozsahu asi $150 \times 170 \mathrm{~km}$, vymezeného umělými politickými hranicemi. Základním předpokladem na této úrovni je existence několika rozsáhlých sídelních enkláv s hustým kontinuálním osídlením po celou dobu bronzovou, $\mathrm{k}$ nimž se v některých obdobích připojují i další okrajové sídelní oblasti (Podborský a kol. 1993, mapky 18-24; Obr. 1). Aktuální studie zaměřené primárně (Olomoucko - Vránová 2013; Brno - Salaš 2011) či okrajově (Boskovicko Štrof 2014) na poznání sídelní struktury v detailnějším pohledu konstatují ve značné shodě pro dobu bronzovou existenci husté a dlouhodobě stabilní sídelní sítě. Základem jsou zpravidla jednotlivé přirozené mikroregiony, v jejichž rámci existují dlouhodobě využívané sídelní polohy s centrálními pohřebišti, doplněné dalšími krátkodobými lokalitami. Tato představa odpovídá modelovým studiím sídelních areálů doby bronzové v Čechách (Lužický potok, Hříměždický potok; souhrnně Jiráň a kol. 2008, 161-164).

Lze tedy předpokládat, že rozsáhlé, systematicky archeologicky sledované liniové stavby v podobě dálnic a rychlostních komunikací vedoucích napříč v pravěku intenzivně využívanou starou sídelní oblastí by měly při sledování dostatečně rozsáhlého vzorku přinášet informace o jednotlivých úsecích doby bronzové ve srovnatelném množství. Pro ověření této teze byla kompletně shromážděna data ze záchranných výzkumů v trase dálnice Brno Kroměříž, budované a bezezbytku systematicky zkoumané v letech 1979-2007. V této „sondě krajinou“ o délce 54,5 km je evidováno celkem 68 archeologicky pozitivních lokalit s řadou komponent datovaných do širokého rozpětí od neolitu po novověk (Tab. 1), na polovině z nich (34) jsou doloženy stopy aktivit z doby bronzové (sumárně Tab. 2). Jejich časové i prostorové rozložení je ovšem překvapivě nerovnoměrné (Obr. 2,3). Především je pozoruhodné, že se ani jednou nepodařilo spolehlivě zachytit komponenty pozdní doby bronzové (jako mladší doba bronzová je chápáno rozmezí stupňů B D-Ha A2, jako pozdní stupeň Ha B) a pouze jednou byly zachyceny aktivity z navazující doby halštatské (Křenovice 2; původně předpokládaná přítomnost komponent pozdní doby bronzové v této poloze je po upřesnění předběžných informací nepravděpodobná; Tajer - Vránová 2011). Zdaleka nejpočetnější jsou komponenty starší a mladší doby bronzové, aktivity starší doby bronzové jsou nejrovnoměrněji rozloženy v prostoru. Převaha starobronzových aktivit zůstává i při zohlednění délky jednotlivých časových úseků - pro součet lokalit únětické kultury a věteřovské skupiny vychází 6,8 komponenty na 100 let (rámcově 2000-1600 BC; protoúnětická pohřebiště nejsou zohledněna), pro mladý bronz 5,2 komponenty na 100 let (rámcově 


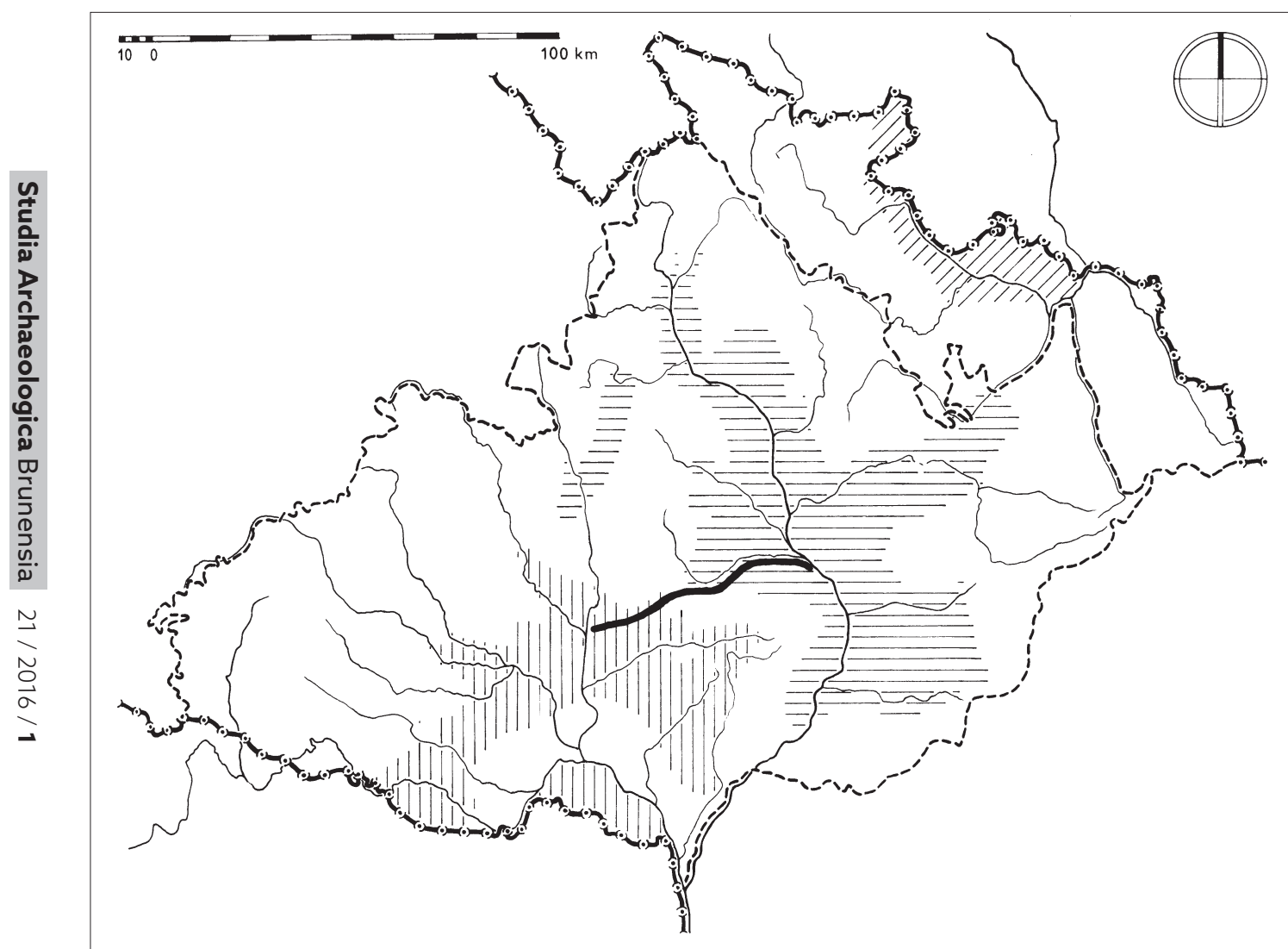

Obr. 1. Osídlení Moravy v pozdní době bronzové dle Podborský a kol. 1993, mapka 24, upraveno a vynesen sledovaný úsek dálnice Brno-Kroměříž.

Fig. 1. Final Bronze Age settlement in Moravia after Podborský a kol. 1993, map 24, modified, the examined segment of motorway Brno-Kroměřiž is highlighted.

1300-1050 BC; k absolutní dataci např. Primas 2008, Abb. 1.3; Roberts - Uckelmann - Brandherm 2013, Fig. 2.1).

Výsledek je jednoznačný - poměrně reprezentativní soubor (n=34) zkoumaných komponent doby bronzové z liniové stavby procházející starou sídelní oblastí na pomezí jižní a střední Moravy je v prostoru i čase rozdělen velmi nerovnoměrně. Jak vysvětlit takovouto strukturu dat? Projevují se zde odlišné preference využívaní poloh v krajině, charakter a zachytitelnost archeologických pramenů, nebo zásadní proměny celé sídelní sítě v jednotlivých obdobích? Pro řešení těchto otázek byla níže shromážděna všechna dostupná data z dosud nejlépe zpracovaného regionu Vyškovské brány, a to především se zaměřením na $\mathrm{v}$ trase dálnice „chybějící komponenty pozdní doby bronzové.

\section{Dostupné prameny - základní charakteristika}

Šíreji pojatý prostor Vyškovské brány byl pro účely studia sídelních struktur doby bronzové vybrán především díky kvalitním souborům archeologických dat, v jádru jde ovšem i o přirozenou geomorfologickou jednotku, součást celku 


\begin{tabular}{|c|c|c|c|}
\hline Lokalita & Výzkum & Komponenty & Zákl. literatura \\
\hline Bedřichovice & $1979-1980$ & $\begin{array}{l}\text { en.zvo, br-une, br-pun } \\
(p) \text {, laten }(p)\end{array}$ & $\begin{array}{l}\text { PV1979; PV 1980; Čižmář - Geisler } \\
\text { 1998; Čižmář - Dvořák 1985; Čižmář } \\
1985\end{array}$ \\
\hline Bedřichovice I & 1979 & rim & PV 1979 \\
\hline Tvarožná I & 1979 & br.une $(s+p)$ & PV 1979 \\
\hline Tvarožná II & 1979 & br.une $(p)$ & PV 1979 \\
\hline Tvarožná III & 1979 & lengye, en.snu (p) & $\begin{array}{l}\text { PV 1979; Čižmáŕ - Geisler 1998; } \\
\text { Rakovský 1985c }\end{array}$ \\
\hline Holubice & 1979 & eneoli & PV 1979 \\
\hline Holubice I & $\begin{array}{l}1979-1980, \\
1985\end{array}$ & $\begin{array}{l}\text { en-zvo, br.une, snarod } \\
(s+p) \text {, br.vel }\end{array}$ & PV 1979; PV 1980; Rakovský 1985a \\
\hline Holubice II & $1979-1980$ & br.une, br.moh, lengye & PV 1979; PV 1980 \\
\hline Holubice III & 1980,1982 & lengye, br.une $(s+p)$, ri-st & PV 1980; PV 1982; Šedo 1985 \\
\hline Holubice IV & 1981 & $\begin{array}{l}\text { ne.lin, en.zvo (p), en-snu } \\
\text { (p), br.ml }\end{array}$ & $\begin{array}{l}\text { PV 1981; Čižmářr - Geisler 1998; Geis- } \\
\text { lerová 1985; Rakovský 1985b }\end{array}$ \\
\hline Holubice V & 1981 & br.une (p), rs.3 (p) & PV 1981; Geisler 1985 \\
\hline Holubice VI & 1981 & br.une, rs.3 (p), rs.4 (p) & PV 1981; Geisler 1992 \\
\hline Holubice VIII & 1985 & en.zvo (s+p) & PV 1985 \\
\hline Velešovice I & 1985 & en.snu (p) & PV 1985; Čižmář - Geisler 1998 \\
\hline Velešovice & 1985-1988 & $\begin{array}{l}\text { lengye, en.snu }(p), \\
\text { en.zvo, br.une }(s+p), \\
\text { snarod }(p)\end{array}$ & $\begin{array}{l}\text { PV 1985; PV 1986; PV 1987; PV 1988; } \\
\text { Čižmář - Geisler } 1998\end{array}$ \\
\hline Slavíkovice & 1985 & ne.lin, lengye, laten & PV 1985; Čižmář - Geislerová 1997 \\
\hline Rousínovec & 1985 & $\begin{array}{l}\text { en.nal, en.snu (p), en.zvo } \\
\text { (p) }\end{array}$ & PV 1985; Čižmář - Geisler 1998 \\
\hline Kroužek & 1985 & en.jor, en.snu (p), br.une & PV 1985; Čižmář - Geisler 1998 \\
\hline Komořany & 1985 & br.ml & PV 1985 \\
\hline Tučapy & 1989 & en.snu (p), br.une & PV 1989 \\
\hline Nemojany & 1989 & en.zvo & PV 1989 \\
\hline Vyškov - Žleby & 1989-1991 & ri.ml, rs.3 & PV 1989; PV 1990; PV 1991 \\
\hline Vyškov - Návrší nad Žleby & 1989 & en.snu (p) & PV 1989 \\
\hline $\begin{array}{l}\text { Vyškov - U benzínové } \\
\text { pumpy }\end{array}$ & 1989 & br.une, br.vet & PV 1989 \\
\hline Vyškov - Ostrovy & $1989-1990$ & laten & PV 1989, PV 1991 \\
\hline Vyškov - Prostřední pole & 1989 & br.ml & PV 1989 \\
\hline Vyškov - Manské & 1990 & la.d & PV 1990; Horálková 1993 \\
\hline Vyškov 1 & 2002 & br.moh & PV 44 \\
\hline Vyškov 2 & 2002 & pr.zem & PV 44 \\
\hline Vyškov 3 & 2002 & la.b-d & PV 44 \\
\hline
\end{tabular}




\begin{tabular}{|c|c|c|c|}
\hline Lokalita & Výzkum & Komponenty & Zákl. literatura \\
\hline Topolany 1 & 2002 & pr.zem & PV 44 \\
\hline Topolany 2 & 2002 & $\begin{array}{l}\text { lengye, en.kan, en.zvo, } \\
\text { br.pun (p), br.moh, br.ml, } \\
\text { rs.3 (s+p) }\end{array}$ & PV 44; Parma 2011 \\
\hline Topolany 3 & 2002 & $\begin{array}{l}\text { en.zvo, br.pun (p), br.une, } \\
\text { rs.3 (p) }\end{array}$ & PV 44 \\
\hline Heroltice 1 & 2002 & en.zvo & PV 44 \\
\hline Hoštice 4 & 2002 & $\begin{array}{l}\text { en.snu }(p) \text {, en.zvo }(p), \\
\text { br.une }(s+p) \text {, br.ml }(s+p) \text {, } \\
\text { la.b }(p) \text {, snarod }\end{array}$ & $\begin{array}{l}\text { PV 44; Parma 2011; Matějičková - } \\
\text { Dvořák eds. 2012; Kolář a kol. } 2011\end{array}$ \\
\hline Hoštice 3 & 2002 & en.zvo, ri-sn (p) & PV 44 \\
\hline Hoštice 2 & 2002 & en.zvo & PV 44 \\
\hline Hoštice 1 & 2002 & en.zvo (p) & $\begin{array}{l}\text { PV 44; Matějičková - Dvořák eds. } \\
2012\end{array}$ \\
\hline Medlovice 1 & 2002 & lengye, br.ml, la.b-d, rim & PV 44; Parma 2011 \\
\hline Ivanovice n. H. 3 & 2002 & $\begin{array}{l}\text { en.nal, en.zvo, br.une, } \\
\text { br.moh, br.ml }\end{array}$ & PV 44; Parma 2011 \\
\hline Ivanovice n. H. 3/2 & 2002 & $\begin{array}{l}\text { lengye, en.snu (p), } \\
\text { br.une, br.moh (p), br.ml } \\
\text { (p) }\end{array}$ & PV 44; Parma 2011; Koláŕ a kol. 2011 \\
\hline Ivanovice n. H. 4 & 2002 & en.nal, en.snu (p) & PV 44; Kolář a kol. 2011 \\
\hline Ivanovice n. H. 5 & 2002 & br.une & PV 44 \\
\hline Ivanovice n. H. 6 & $2002-2003$ & en.zvo (p), br.ml & PV 44; PV 45; Parma - Šmíd 2013 \\
\hline Ivanovice n. H. 7 & $2002-2003$ & $\begin{array}{l}\text { ne.lin, en.snu (p), br.pun } \\
\text { (p), br.une, br.moh, br.ml }\end{array}$ & PV 44; PV 45; Parma - Šmíd 2013 \\
\hline Tištín 5 & 2002 & lengye, en.zvo & PV 44 \\
\hline Tištín 6 & 2002 & en.zvo, br.une & PV 44; Matějičková - Dvořák eds. 2012 \\
\hline Tištín 7 & 2002 & pr.zem & PV 44 \\
\hline Nezamyslice 1 & 2002 & lengye, ri.sn (p), rs.3 & PV 44 \\
\hline Nezamyslice 2 & 2002 & lengye, en.kan & PV 44 \\
\hline Nezamyslice 3 & 2002 & pr.zem, vs.2 & PV 44 \\
\hline Mořice 1 & 2002 & br.une $(s+p)$, rim & PV 44 \\
\hline Mořice 2 & 2002 & en.snu (p), rs.4 (p) & PV 44; Kolář a kol. 2011 \\
\hline Vrchoslavice 1 & 2004 & br.st, rim & PV 46 \\
\hline Vrchoslavice 2 & 2004 & $\begin{array}{l}\text { br.st }(s+p) \text {, laten, rim, } \\
\text { snarod }(p)\end{array}$ & PV 46 \\
\hline Vrchoslavice 3 & 2004 & br.st (s+p), br.ml (p) & PV 46 \\
\hline Vrchoslavice 4 & 2005 & novove & PV 47 \\
\hline Vrchoslavice - Vitčice 1 & 2006 & $\begin{array}{l}\text { en.snu (p), en.zvo (p), } \\
\text { br.vet, rim }\end{array}$ & Tajer 2007 \\
\hline
\end{tabular}




\begin{tabular}{|l|c|l|l|}
\hline \multicolumn{1}{|c|}{ Lokalita } & \multicolumn{1}{c|}{ Výzkum } & \multicolumn{1}{c|}{ Komponenty } & \multicolumn{1}{c|}{ Zákl. literatura } \\
\hline Stř́brnice 1 & 2006 & en.snu (p), en.zvo (s+p) & Peška - Tajer 2007 \\
\hline Křenovice 1 & 2006 & en.jev & PV 48 \\
\hline Křenovice 2 & $2006-2007$ & $\begin{array}{l}\text { lengye, en.jev, br.vet, } \\
\text { br.moh, br.ml, halsta, } \\
\text { rstred (p), novove }\end{array}$ & $\begin{array}{l}\text { PV 48; PV 49; Peška - Tajer 2009; } \\
\text { Tajer - Vránová 2011 }\end{array}$ \\
\hline Křenovice 3 & 2007 & br.vet, rs.3 & PV 49; Daňhel - Pankovská 2008 \\
\hline Popůvky 1 & 2007 & rim & PV 49 \\
\hline Bezměrov 1 & $2005-2006$ & en.snu (p) & PV 48 \\
\hline Kroměřiž & $2003-2005$ & $\begin{array}{l}\text { ne.lin, lengye, en.nal, } \\
\text { br.st (p), br.ml (s+p), } \\
\text { halsta }\end{array}$ & PV 46, PV 47 \\
\hline Kroměříž & 2004 & paleoli & PV 46 \\
\hline Kroměřiž 3 & $2005-2006$ & lengye, en.jev (s+p) & $\begin{array}{l}\text { PV 47; PV 48; Peška - Tajer 2006; } \\
\text { Peška - Tajer 2009 }\end{array}$ \\
\hline Kroměříž & 2006 & bronz & PV 48 \\
\hline
\end{tabular}

Tab. 1. Přehled lokalit zkoumaných v letech 1979-2007 v trase dálnice Brno - Kroměříž; odkazy na zprávy v Přehledech výzkumů (PV) uvedeny zjednodušenou formou, zkratky dle hesláře SAS (Sklenářová a kol. 1996), s - sídelní, $\mathrm{p}$ - pohřební komponenta.

Tab. 1. An overview of localities examined in 1979-2007 in the motorway route Brno - Kroměříz; references to reports in Přehledy výzkumů (PV) are given in a simplified form, abbreviations are given according to the SAS index (Sklenářová a kol. 1996), s - settlement component, p - funerary component.

Západních Vněkarpatských sníženin. Jedná se o tektonickou sníženinu oddělující Drahanskou vrchovinu s pestrou skladbou hornin především paleozoického stáří na severozápadě a Litenčickou pahorkatinu s uniformními sledy paleogenního a neogenního stáří na jihovýchodě (Demek - Mackovčin eds. 2006, 510). Z širšího geografického hlediska se jedná o klasický tranzitní prostor, v němž můžeme předpokládat existenci komunikace spojující minimálně oblast Brněnska s nížinou Hané. Hydrologickou osou oblasti je tok Hané, pravobřežního přítoku Moravy, jihovýchod i sever sledované oblasti člení řada souběžných drobných vodotečí, kolem nichž se do značné míry shlukuje pravěké osídlení. Severozápadní okraj vymezují poměrně výrazně modelované svahy Drahanské vrchoviny, dlouhodobě v pravěku využívané k zakládání výšinných, případně i opevněných sídlišst.
Hranice sledovaného prostoru byly uměle vymezeny jako širší prostor katastrálních území 34 obcí (Obr. 4, pozn. 1) o rozloze 234 $\mathrm{km} 2$, a to s ohledem na dostupnost nálezových souborů uložených především v Muzeu Vyškovska ve Vyškově. Základní soubor dat pochází z drobných záchranných akcí z 50. až 80. let 20. století, větších výzkumů v trase dálnic z 80. let, a ze systematické záchranné činnosti realizované od 90 . let 20. století především specializovaným vyškovským pracovištěm Ústavu archeologické památkové péče Brno. Souběžně s „profesionálně“ získanými daty je ovšem v regionu díky dlouhodobému působení několika zájemců o archeologické památky $\mathrm{k}$ dispozici i početný soubor dat z povrchových průzkumů. E. Černý a jeho následovník M. Režný zaměřovali pozornost především na zalesněnou oblast Drahanské vrchoviny, vý- 

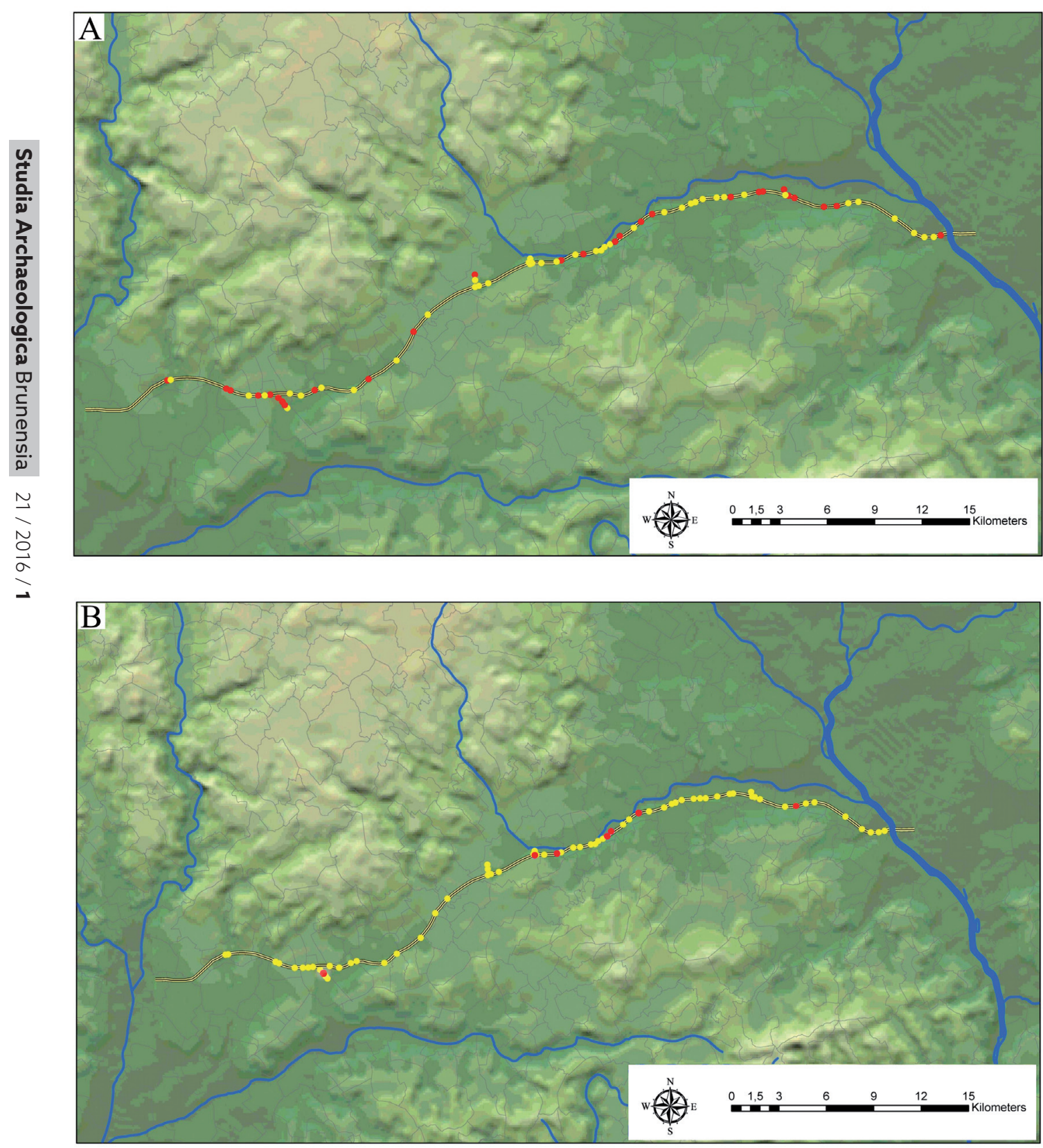

Obr. 2. Trasa dálnice Brno - Kroměříž, zachycené lokality sledovaných časových úseků vyznačeny červeně na pozadí všech zkoumaných lokalit (žlutě): A - starší doba bronzová, B - střední doba bronzová.

Fig. 2. Motorway route Brno - Kroměřǐz, identified localities from the time spans under review are marked in red on the background of all sites examined (yellow): A - Early Bronze Age, B - Middle Bronze Age. 

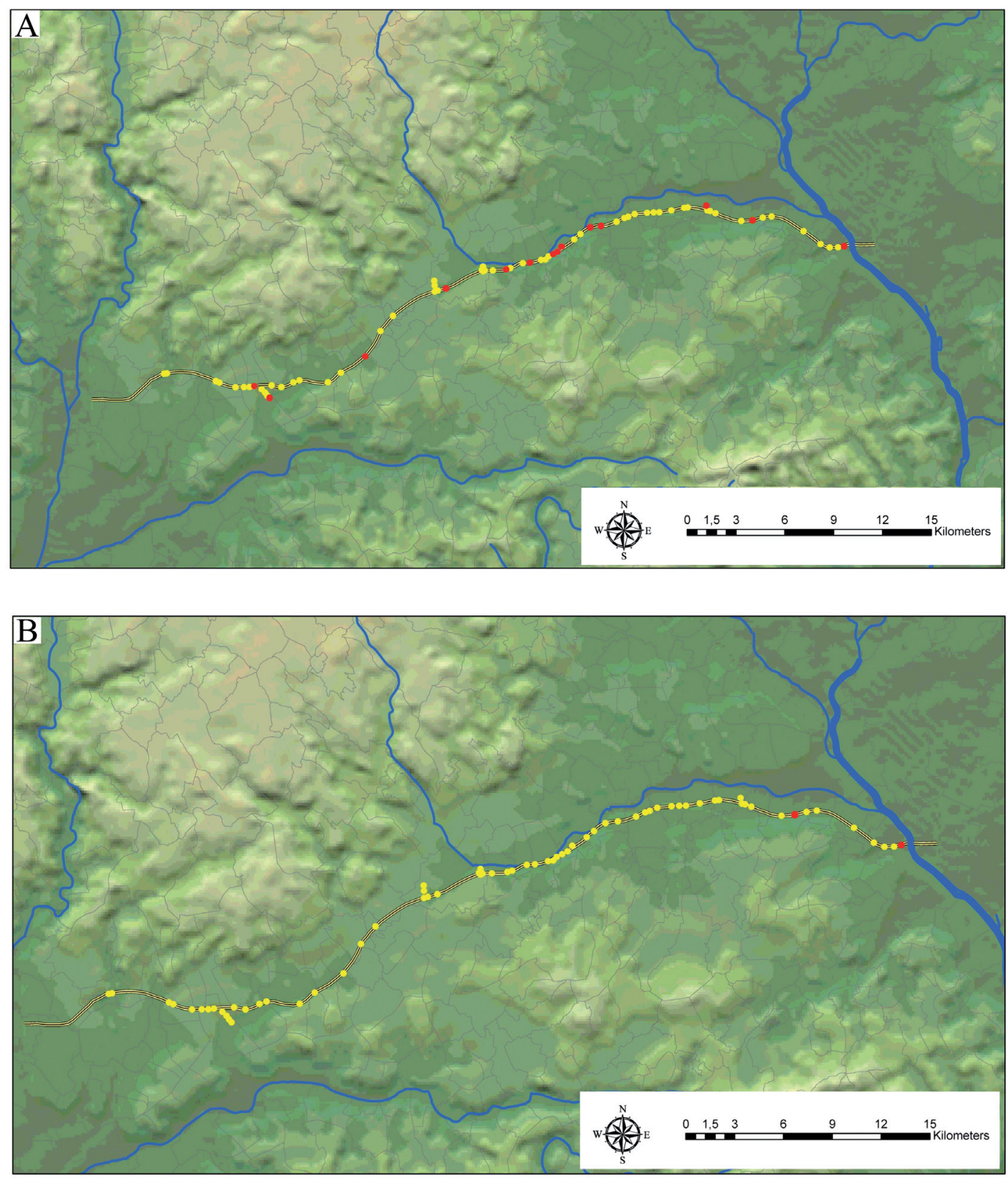

Obr. 3. Trasa dálnice Brno - Kroměříž, zachycené lokality sledovaných časových úseků vyznačeny červeně na pozadí všech zkoumaných lokalit (žlutě): A - mladší doba bronzová, B - doba halštatská; komponenty pozdní doby bronzové nebyly zjištěny; soupis viz Tab. 1.

Fig. 3. Motorway route Brno - Kroměříz, identified localities from the time spans under review are marked in red on the background of all sites examined (yellow): A - Late Bronze Age, B - Hallstatt Period; components of Final Bronze Age were not detected; the list see in Tab. 1. 


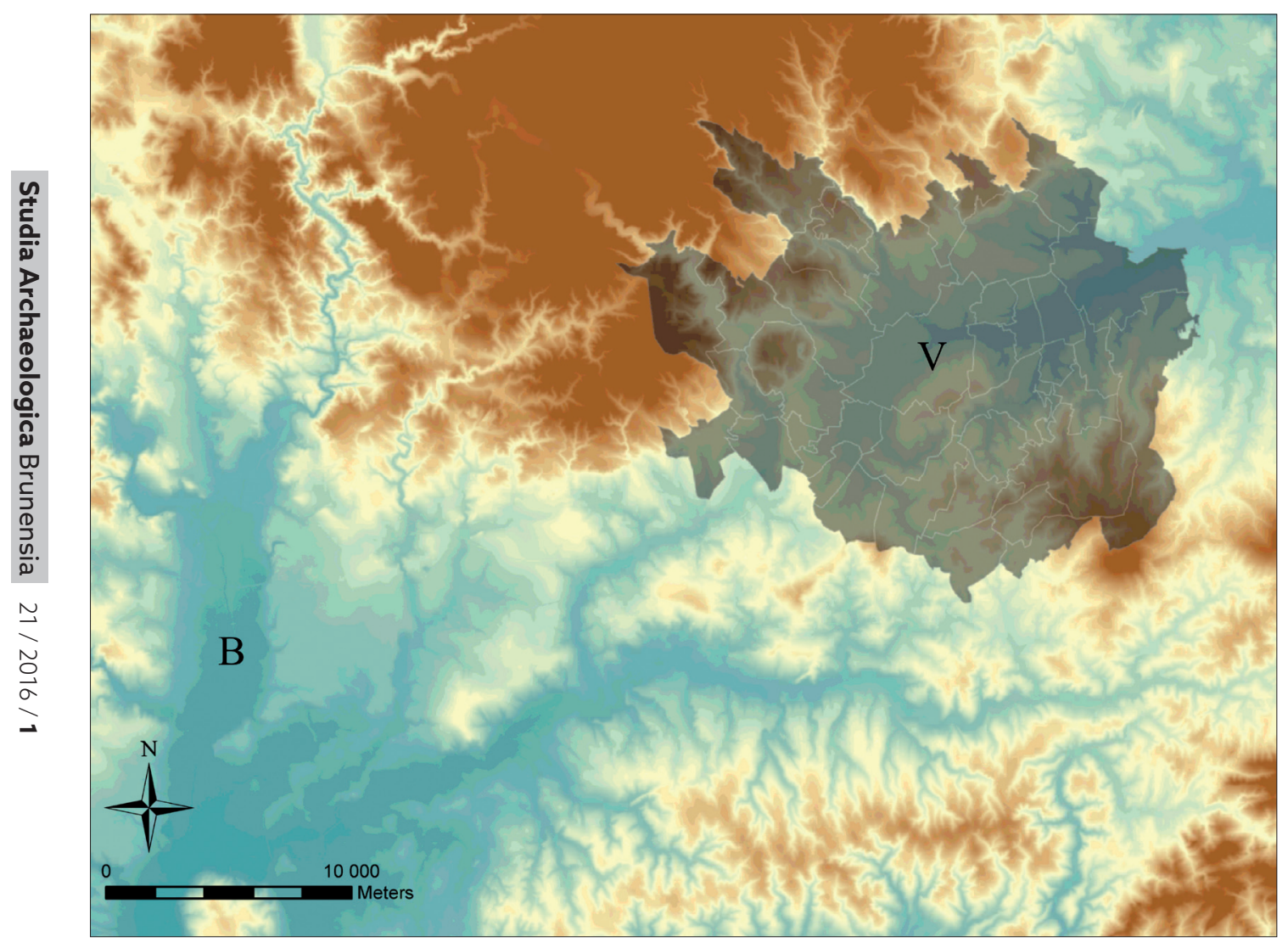

Obr. 4. Poloha a vymezení zájmového regionu v prostoru Vyškovské brány; orientační body: B - Brno, V - Vyškov.

Fig. 4. Location and delimitation of the region of interest in the area of the Vyškov Gate; orientation points: B - Brno, V-Vyškov.

konný sběratel M. Daněk od 70. let 20. století shromáždil enormně početnou kolekci nálezů z povrchových sběrů z okolí Drnovic.

Při tvorbě soupisů byly brány v potaz pouze jednoznačně lokalizované a datované soubory artefaktů. Vzhledem k nejasnostem při stanovení stáří v literatuře byly na základě nálezů důsledně ověřeny všechny lokality ze střední, mladší a pozdní doby bronzové a z doby halštatské, podstatná část nálezů ze střední až pozdní doby bronzové je v současné době zpracována a kresebně dokumentována. Nevýrazné soubory datovatelné jen v rámci širokých intervalů byly ze soupisů vyřazeny. Osídlení starší doby bronzové dosud v celém prostoru takto kompletně revidováno nebylo pro značný objem dat. Klíčové plošně zkoumané lokality jsou dostupné alespoň ve formě katalogů (viz níže), kompletně inventována a datována byla i sbírka M. Daňka, v současné době uložená v Muzeu Vyškovska; nálezy sledovaného období doby bronzové a halštatské byly poměrně spolehlivě lokalizovány dle původního označení polních tratí a kresebně dokumentovány (Parma - Holubová 2015).

$\mathrm{V}$ terminologickém a chronologickém rozlišení komponent mladší a pozdní doby bronzové z Vyškovska dosud panovala v literatuře značná nejednotnost, což částečně vyplývá z polohy na 
rozhraní obou předpokládaných hlavních kulturních okruhů, lužického a středodunajského. Na tomto místě je používána kulturně neutrální terminologie vycházející z jednotlivých nadregionálních chronologických stupňů a zastřešujícího pojmu kultura popelnicových polí (dále KPP; Salaš 2005, Obr. 1; podrobně k problematice Parma v tisku). Chronologické zařazení lokalit je založeno především na souborech keramiky. Sekvenci pro lokality střední a mladší doby bronzové bude věnována detailní pozornost na jiném místě, zde lze pro upřesnění stanovit alespoň některé základní trendy ilustrované výběrem materiálu (Obr. 5, 6). Soubory střední doby bronzové se vyznačují především charakteristickou zahloubenou výzdobou (linie rýžek, ryté trojúhelníky atd.) a absencí úpravy povrchu tuhováním (Obr. $5 \mathrm{~A})$. Soubory z časného stupně KPP jsou jen obtížně vyčlenitelné, nebot je tvoří především nezdobená keramika, ovšem již s podílem keramiky s tuhovaným povrchem. Mezi charakteristické tvary patří zejména mísy se zduřelým okrajem (Obr. 5B). Pro starší stupeň KPP je charakteristická tvarová skladba s ostře lomenými nádobami (mísy, dvoukonické nádoby, šálky) a výrazné zastoupení úpravy povrchu rýhováním (Obr. 5C). Pro střední stupeň KPP jsou typické soubory s esovitě profilovanými šálky s vysokým uchem a mísami s vnitřně tordovaným okrajem (Obr. 5D). Ve starším i středním stupni KPP se objevují mísy s vně hraněným nebo tordovaným okrajem a nepočetná keramika zdobená svislým nebo šikmým žlábkováním. Výrazně odlišné je keramické spektrum z lokalit pozdní doby bronzové (Obr. 6). Nejcharakterističtější prvky představuje masivní přítomnost tenkostěnných šálků s oběžnou vnitřní i vnější výzdobou a podobným stylem zdobené amforovité nádoby. Různé kombinace vodorovné ryté a žlábkované oběžné výzdoby hrdla a svislé a obloukovité výzdoby na výduti ukazují jednoznačně na zastoupení forem mladšího i pozdního stupně KPP (mladší a konečný vývojový stupeň KLPP v pojetí J. Nekvasila; Nekvasil 1970). Jestliže početná keramika ze sídelních komponent staršího a středního stupně KPP projevuje jasné stylové vazby na středodunajskou, popř. středočeskou oblast, od mladšího stupně KPP je jednoznačná stylová vazba na středomoravské „lužické“ prostředí.

Podstatnou roli v archeologické ,viditelnosti“ osídlení jednotlivých období sehrávají kulturně podmíněné a regionálně proměnné faktory jako je prrítomnost/nepřítomnost zahloubených objektů a podíl charakteristicky zdobené keramiky. Základní představu o archeologických projevech a podobě artefaktů z komponent střední a mladší doby bronzové lze získat především z plošných odkryvů v trase dálnice Vyškov-Mořice (zejména lokality Topolany 2, Hoštice 4, Ivanovice n. H. 3, 6, 7; Parma 2011; Parma - Šmíd 2013), dále doplněných o zpracované lokality Drnovice „Za lesní správou“ (Parma a kol. 2015) a Vyškov „Nouzka (Parma a kol. 2014). Výběrově zveřejněné nálezy z další výrazné lokality Vyškov „Markova cihelna“ (Říhovský 1960), stejně jako v nálezové zprávě vyobrazené soubory z Drysic (Geislerová - Janák 1985), jsou zcela analogické nálezovým profilům lokalit Ivanovice n. H. 6 a 7. Vcelku je zřejmé, že sídelní komponenty střední a mladší doby bronzové se projevují především jako výrazné shluky desítek až stovek zahloubených bodových objektů různých rozměrů a vzhledem k nízkému podílu zdobené keramiky jsou obtížně identifikovatelné v kolekcích z povrchových sběrů. Sídelní areály střední doby bronzové

- Obr. 5. Keramická sekvence závěru střední a mladší doby bronzové v prostoru Vyškovské brány: A - pozdní mohylová kultura, B - časný stupeň KPP, C - starší stupeň KPP, D - střední stupeň KPP.

- Fig. 5. Ceramic sequence of the end of the Middle Bronze Age and the Late Bronze Age in the area of the Vyškov Gate: A - late Tumulus Culture, B - initial phase of the Urnfield Culture, C - early phase of the Urnfield Culture, D - middle phase of the Urnfield Culture. 


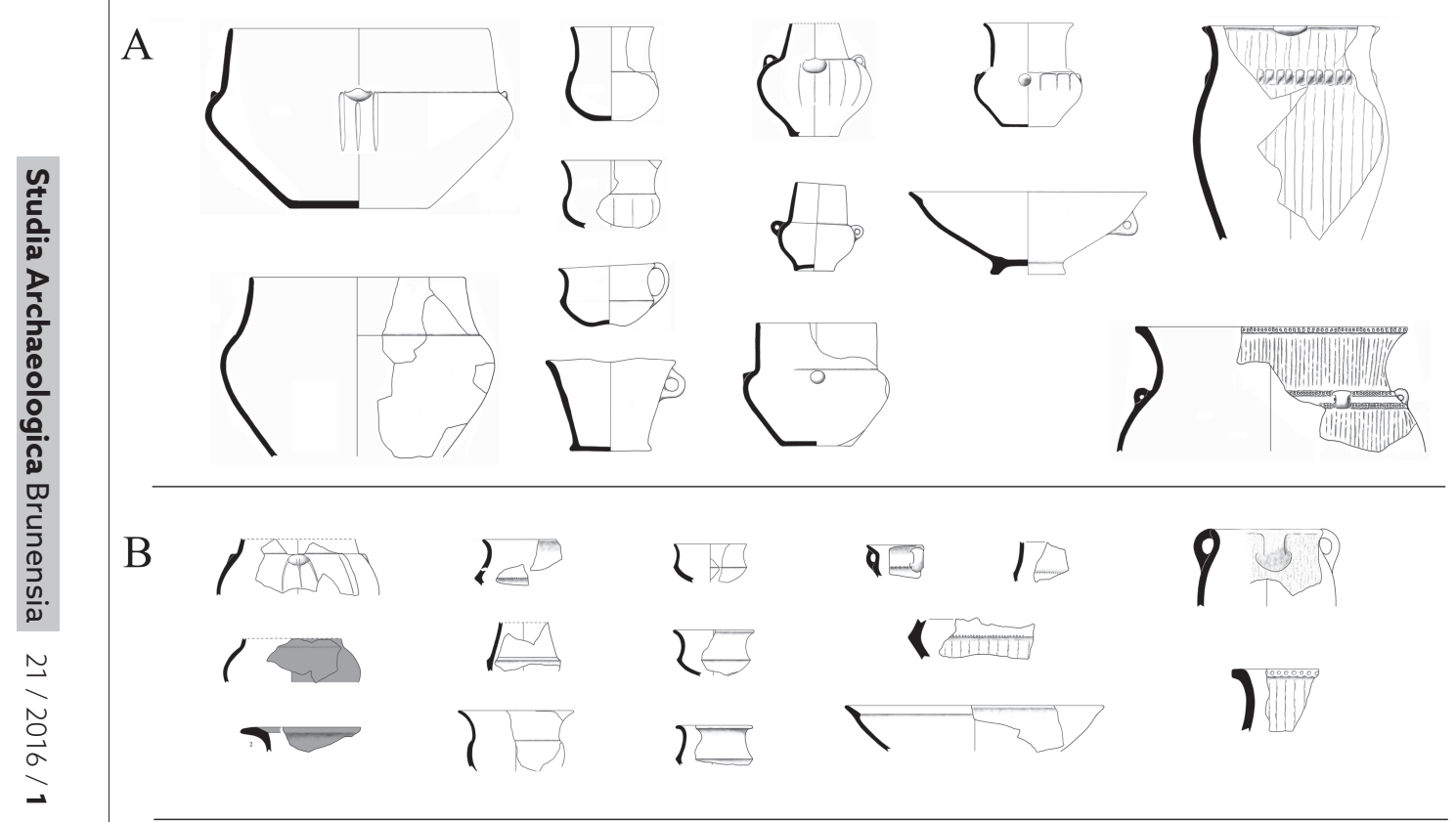

C

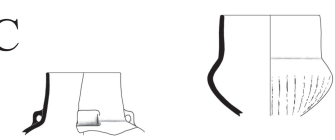

$\rightarrow \infty$

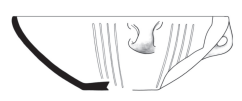

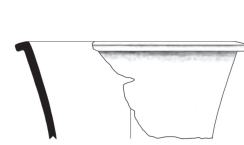

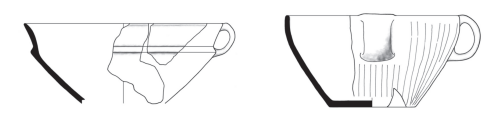
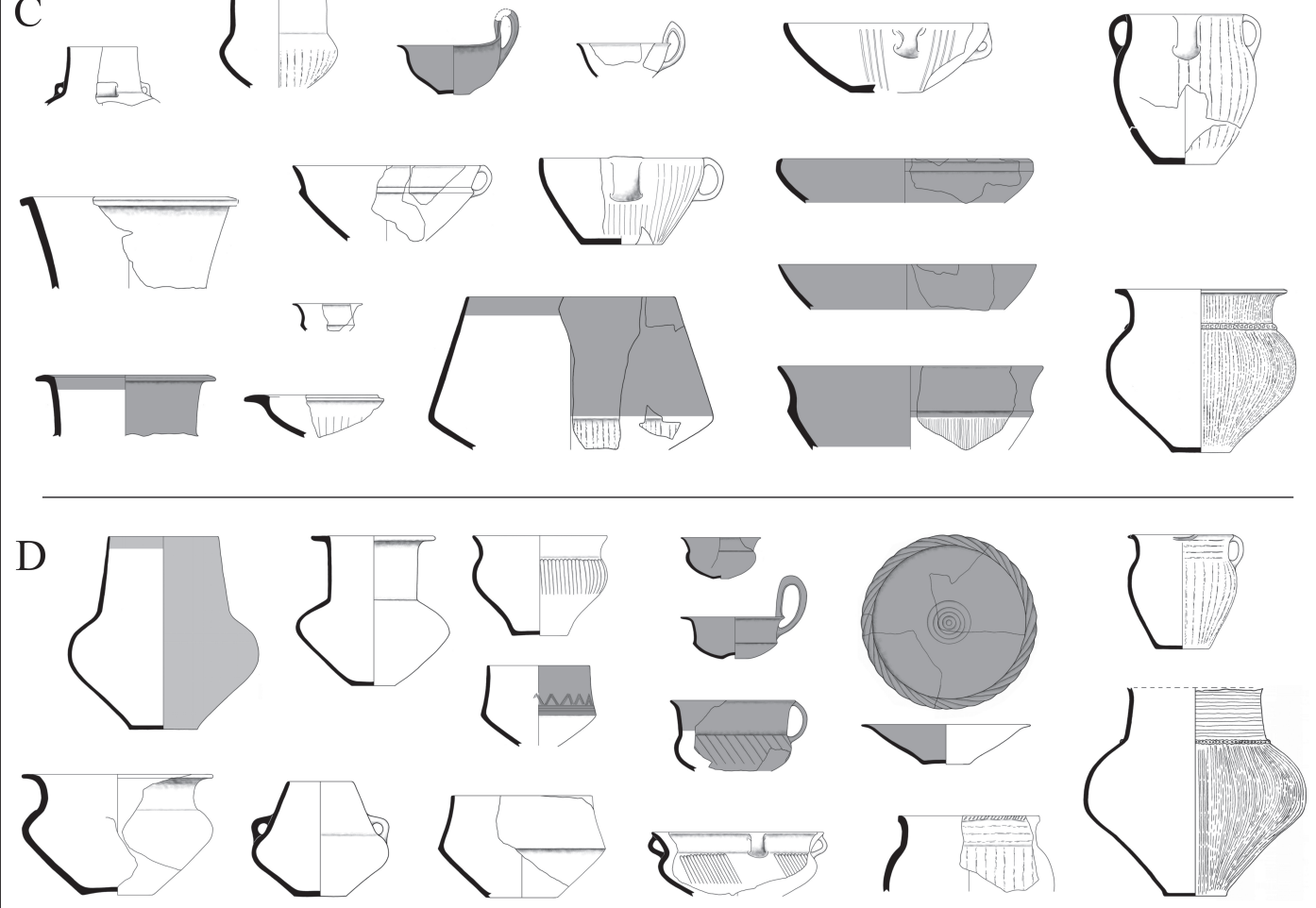


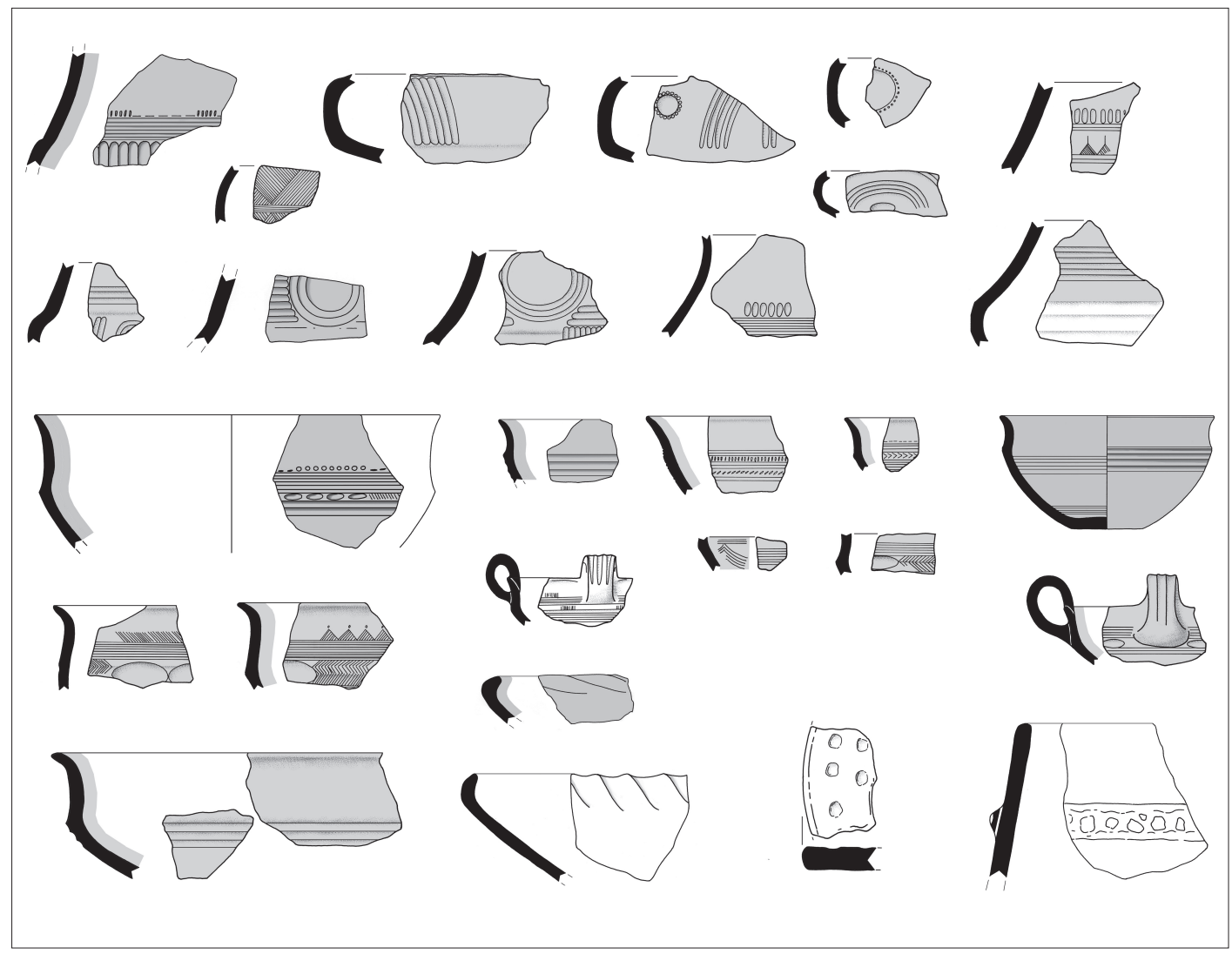

Obr. 6. Výběr keramiky z pozdní doby bronzové z prostoru Vyškovské brány.

Fig. 6. Selection of Final Bronze Age pottery from the area of the Vyškov Gate.

jsou přitom plošně méně rozsáhlé a obtížněji zjistitelné (Parma 2015), z hlediska relativní chronologie patrně bez výjimky náleží mladším úsekům střední doby bronzové. Na žádném z plošně zkoumaných sídelních areálů mladší doby bronzové nelze doložit pokračování aktivit i v pozdní době bronzové, o kontinuitě lze uvažovat pouze u souborů z drobných záchranných akcí a povrchových sběrů. Dostupná data o sídelních komponentách pozdní doby bronzové jsou značně torzovitá, na základě jediné plošně zkoumané lokality v Habrovanech je zřejmé, že se archeologicky projevují běžnými bodovými zahloubenými objekty i kumulace- mi nálezů ve výrazných kulturních souvrstvích. Druhá nejpočetnější kolekce nálezů získaná M. Daňkem z polohy Drnovice „Nivy“ pochází evidentně především z naorávaného souvrství (Parma - Holubová 2015). Podobně zlomkovité jsou poznatky o sídelních areálech doby halštatské, nejpozději v pozdní době halštatské se mezi jejich typické archeologické projevy řadí rozměrné zahloubené objekty s množstvím nálezů, interpretované obvykle jako zahloubené chaty (Habrovany; Parma - Holubová 2015). Keramika z pozdní doby bronzové a v menší míře i z doby halštatské je velmi dobře identifikovatelná díky vysoce charakteristické výzdobě, 


\begin{tabular}{|c|c|c|c|c|c|c|c|c|c|}
\hline Období & bronz & br_st & br_puk & br_une & br_vet & br_moh & br_ml & br_po & halsta \\
\hline Počet komponent & 1 & 4 & 4 & 19 & 4 & 7 & 13 & 0 & 2 \\
\hline
\end{tabular}

Tab. 2. Celkový počet zachycených komponent jednotlivých úseků doby bronzové a halštatu v trase dálnice Brno - Kroměříz.

Tab. 2. Total number of identified components of individual segments of the Bronze Age and the Hallstatt Period in the motorway route Brno - Kroměřiž.

\begin{tabular}{|l|c|c|c|c|}
\hline \multicolumn{1}{|c|}{ Datace } & Střední d.b. & Mladší d.b. & Pozdní d.b. & Halštat \\
\hline & (MBA) & $($ LBA $)$ & (FBA) & (EIA) \\
\hline Clk komponent & 15 & 35 & 15 & 32 \\
\hline Z toho pohreb. arealy & 2 & 9 & 2 & 6 \\
\hline Komponent na 100 let & 5 & 14 & 6 & 9 \\
\hline
\end{tabular}

Tab. 3. Celkový počet zachycených komponent jednotlivých úseků doby bronzové a halštatu v oblasti Vyškovské brány, počet pohřebních komponent a počet komponent na 100 let.

Tab. 3. Total number of identified components of individual segments of the Bronze Age and the Hallstatt Period in the area of the Vyškov Gate, the number of funerary components and the number of components per 100 years.

podíl zdobených zlomků v souborech je díky masovému nástupu oběžné výzdoby nádob vyšší než v předchozím období.

Pohřební areály jsou ve všech případech zachycovány pouze torzovitě (Tab. 3), nejpočetnější jsou do podloží zahloubené žárové hroby $\mathrm{s}$ většími nádobami $\mathrm{z}$ mladší doby bronzové (Hoštice 4, Parma 2007; Švábenice, Trňáčková 1957) a poté komorové hroby z doby halštatské, často opatřené nápadným kamenným závalem (Drnovice „U propasti“, Baarová - Mikulková 2006; Drysice, Baarová 2007). Pohřby ze střední doby bronzové byly obecně zahlubovány spíše minimálně, což dobře dokládají silně porušené kostrové hroby z Ivanovic n. H. 3/2 (Parma 2011, Tab. 75, 76); situaci dále komplikuje patrně i uplatňování pouze výběrového pohřebního ritu. Podobně jen velmi mělce v rámci půdního horizontu byly patrně zahlubovány žárové hroby z pozdní doby bronzové, což vedlo $\mathrm{k}$ jejich devastaci při intenzivní orbě - př́kladem může být skupina téměř zničených hrobů z Kučerova (Mikulková 2013).

\section{Topografie osídlení Vyškovské brány ve střední až pozdní době bronzové a $v$ době halštatské}

Celkově se ve vyčleněném širším regionu Vyškovské brány dosud podařilo identifikovat a lokalizovat celkem 97 komponent datovaných do intervalu střední doba bronzová až doba halštatská (Tab. 3; podrobné soupisy budou publikovány odděleně; pro pozdní dobu bronzovou viz Parma - Holubová 2015). Rozložení v rámci jednotlivých časových horizontů je silně nerovnoměrné, a to i při zohlednění různé délky jejich trvání. V mladší době bronzové je počet známých komponent vůbec nejvyšší (14 na 100 let), následován dobou halštatskou s dvoutřetinovou hodnotou a s výrazným odstupem pak střední a pozdní dobou bronzovou s třetinovými hodnotami (5 a 6 komponent na 100 let). Toto rozdělení četností komponent odpovídá jiné podobné sadě dat - soupisu všech komponent z doby bronzové, zjištěných při záchranných výzkumech ÚAPP Brno v celém okrese Vyškov 


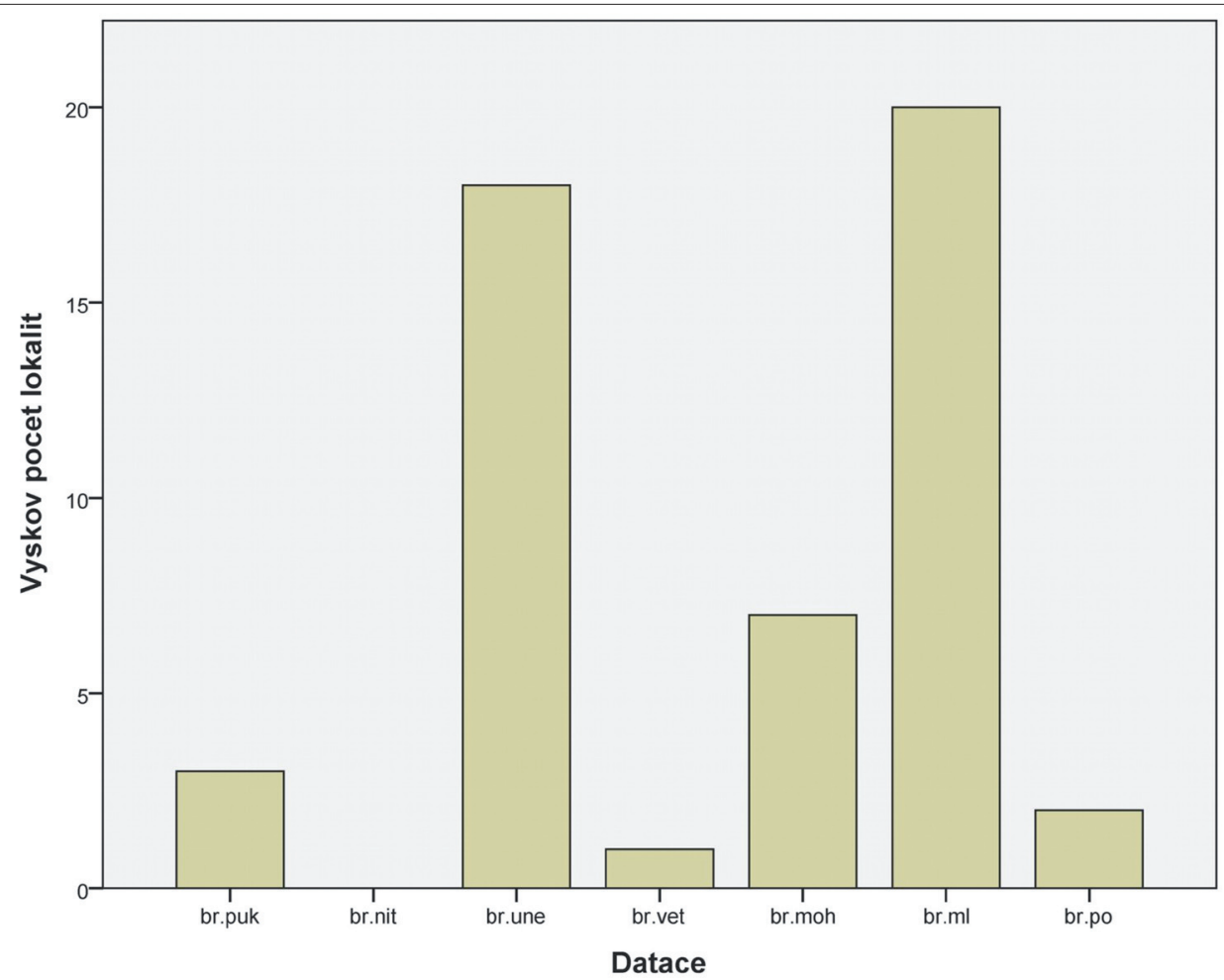

Obr. 7. Rozložení souboru komponent zjištěných při záchranných výzkumech ÚAPP Brno v letech 1993-2010, absolutní četnosti dle jednotlivých kultur: br.puk - k. protoúnětická, br.nit - k. nitranská, br.une - k. únětická, br.vet - věteřovská skupina, br.moh - k. mohylová, br.ml - mladší doba bronzová, br.po - pozdní doba bronzová.

Fig. 7. Distribution of the assemblage of components detected during rescue excavations by the Institute of Archaeological Heritage Brno in 1993-2010, absolute frequencies by individual cultures: br.puk - Proto-Únětice Culture, br.nit - Nitra Culture, br.une - Únětice Culture, br.vet - Věteřov Group, br.moh - Tumulus Culture, br.ml - Late Bronze Age, br.po - Final Bronze Age.

v letech 1993-2010 (Obr. 7). Data se částečně překrývají, druhá sada je ovšem homogennější, nebot' obsahuje pouze výkopem zkoumané komponenty evidované ve dvou svazcích přehledových publikací Výzkumy - Ausgrabungen, tedy výsledky systematické záchranné činnosti jediné instituce působící dlouhodobě v regionu (podrobně Parma 2015).

Geografické rozložení komponent je v rámci jednotlivých horizontů zřetelně rozdílné, a to i přes značnou deformaci obrazu danou způsobem získání dat. Především je nutné zohlednit nerovnoměrný stav poznání jednotlivých ka- tastrů - systematicky po desítky let povrchově sbíraný katastr Drnovic se ukazuje jako výrazný shluk ve všech horizontech. Lze odhadnout, že právě zde se bližíme k poznání reálného počtu původních sídelních komponent a jejich celkový počet (nikoliv ovšem rozložení v rámci časových úseků) by měl být na jiných katastrech alespoň částečně srovnatelný. Dalším zdrojem nehomogenity v souboru dat je trasa dálnice, která zvyšuje počet lokalit pouze v linii vedoucí středem sníženiny.

Všechny komponenty střední doby bronzové až doby halštatské ve Vyškovské bráně jsou 

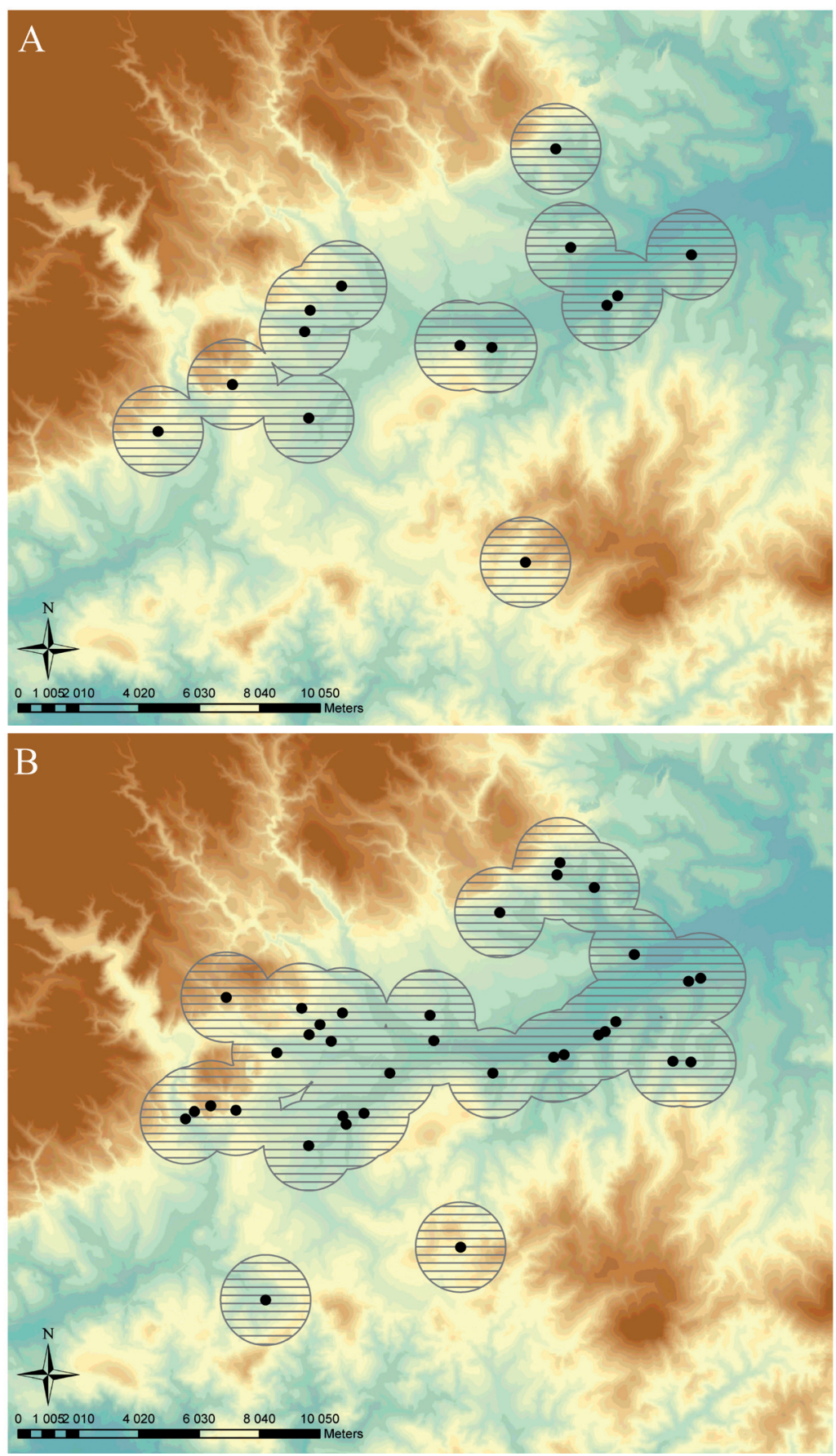

Obr. 8. Komponenty střední (A) a mladší (B) doby bronzové v prostoru Vyškovské brány, vyznačeny obalové zóny o průměru $1,5 \mathrm{~km}$.

Fig. 8. Components of the Middle (A) and Late (B) Bronze Age in the area of the Vyškov Gate, with marked buffer zones of $1.5 \mathrm{~km}$ in diameter. 

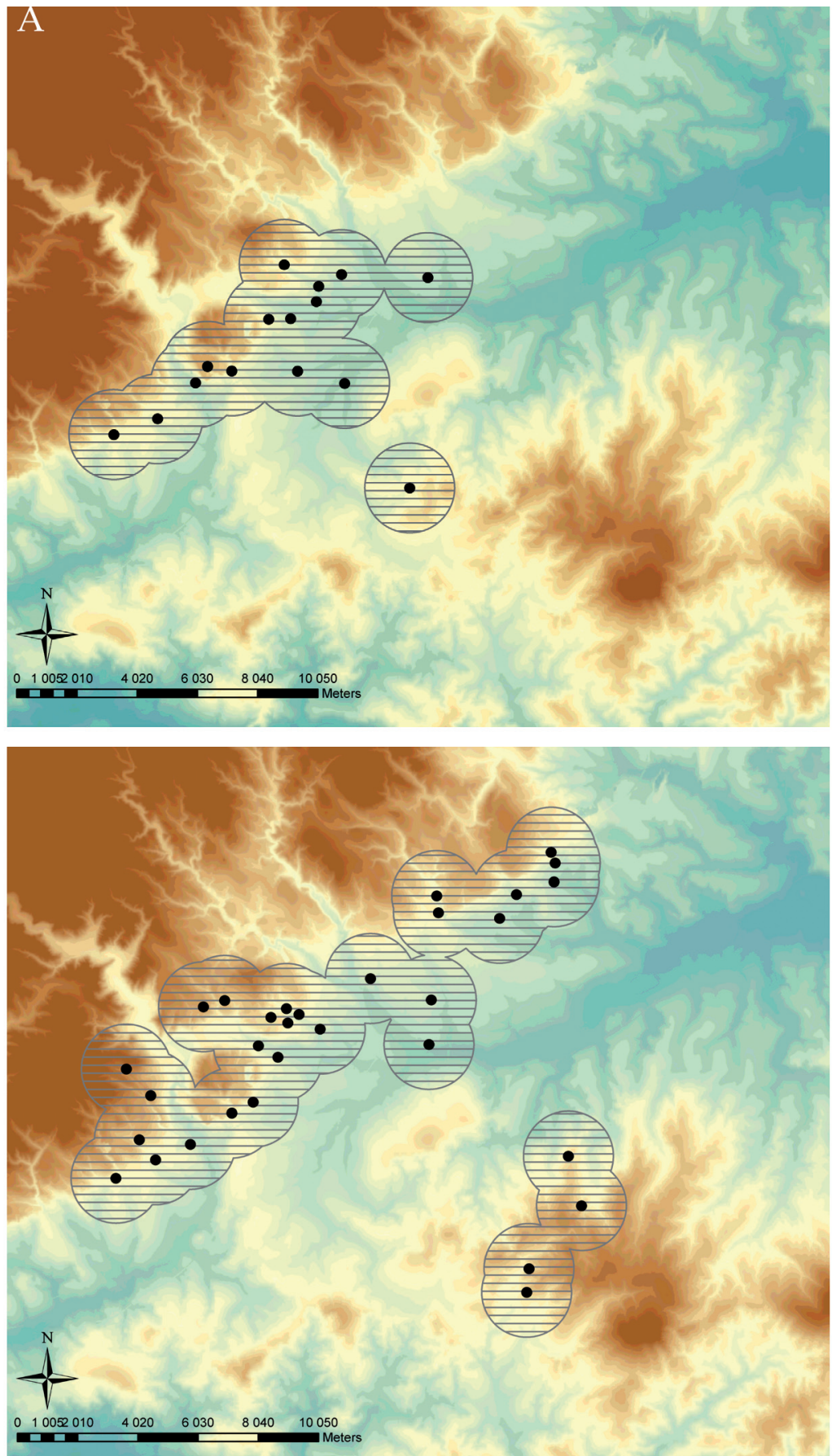

Obr. 9. Komponenty pozdní doby bronzové (A) a doby halštatské $(B) \vee$ prostoru Vyškovské brány, vyznačeny obalové zóny o průměru $1,5 \mathrm{~km}$.

Fig. 9. Components of the Final Bronze Age (A) and the Hallstatt Period (B) in the area of the Vyškov Gate, with marked buffer zones of $1.5 \mathrm{~km}$ in diameter. 
vyneseny do podkladové mapy po jednotlivých horizontech na Obr. 8 a 9, pro vizualizaci využívaného prostoru jsou použity průniky obalových zón o poloměru $1,5 \mathrm{~km}$ od středu lokalit, což odpovídá vzdálenosti do 1 hodiny chůze a tedy ekonomicky intenzivně využitelné zóně. Ve střední době bronzové (Obr. 8A) se polovina známých lokalit nachází v centrální sníženině, ve velmi podobných polohách u drobných jižních přítoků Hané, tedy $\mathrm{v}$ místech trasy dnešní dálnice D1. Další výraznější shluk představuje koncentraci lokalit v Drnovicích, zjištěnou částečně sběry $\mathrm{M}$. Daňka a částečně při záchranných výzkumech (Parma a kol. 2015). V mladší době bronzové (Obr. $8 \mathrm{~B}$ ) je rozložení lokalit v prostoru velmi podobné, pouze jejich počet a rozsah jsou výrazně větší - sledované území je patrně zdaleka nejrovnoměrněji pokryto hustou sítí komponent všeho druhu, často s přímou návazností na starší osídlení středobronzové (9 př́ípadů; $60 \%$ lokalit s komponentou střední doby bronzové má návazné aktivity v mladší době bronzové). Koncentrace lokalit vznikají v tomto případě právě v místech zvýšené aktivity archeologů (trasa dálnice, okolí Drnovic). K výrazné změně dochází s počátkem pozdní doby bronzové (Obr. 9A). Známých komponent je méně a jsou rozloženy nerovnoměrně - objevují se výhradně v západní části sledovaného sektoru jako shluk lokalit v úzkém pásu na jižním úpatí Drahanské vrchoviny. Návaznost na komponenty mladší doby bronzové je výrazně nižší, pouze v 6 případech (jen $17 \%$ lokalit s komponentou mladší doby bronzové vykazuje aktivity i v pozdní době bronzové). Aktivita M. Daňka vedla k objevu 8 komponent $\mathrm{v}$ tomto prostoru, naopak aktivity ve všech dálničních stavbách nevedly k objevu ani jedné. Evidentně došlo k vyklizení podstatné části sledovaného prostoru a původně rovnoměrně rozložená sít lokalit byla nahrazena jediným prostorově úzce vymezeným shlukem (oblast Habrovany - Luleč - Drnovice); pouze zde dochází k částečné návaznosti na komponenty mladší doby bronzové. $\mathrm{V}$ době halštatské dochází opět k nárůstu počtu lokalit, jež svým výrazně nerovnoměrným rozložením přímo navazují na situaci z pozdní doby bronzové (Obr. 9B). Opět se objevují pouze shluky lokalit v okrajových zónách, tentokráte dva odděleně v širším pásu při jižním a východním okraji Drahanské vrchoviny (první v prostoru Habrovany - Luleč - Drnovice, druhý Pustiměř - Radslavice - Drysice), třetí náznakově na jižním okraji na svazích Litenčických vrchů (Orlovice). Centrální sníženina podél Hané zůstává zcela bez osídlení.

Pokud byla v úvodu formulována otázka po příčině absence komponent pozdní doby bronzové a doby halštatské v trase dálnice Brno Kroměříž, odpověd' je zřejmá. Minimálně v případě oblasti Vyškovské brány platí, že lokality obou období zde nechybí, ovšem nacházejí se jednoduše zcela jinde. Tento jednoduchý závěr ovšem vyvolává řadu otázek - především co je důvodem pro zásadní změnu sídelní struktury od počátku pozdní doby bronzové? Ve srovnatelně zpracované oblasti Olomoucka jsou lokality mladší doby bronzové až doby halštatské rozloženy v prostoru nerovnoměrně v jednotlivých shlucích, ty jsou ovšem využívány dlouhodobě a kontinuálně (Vránová 2013, 66-68, Obr. 26). Vymapování lokalit v Boskovické brázdě ukazuje stejný trend - kontinuální využívání celého dostupného prostoru (Štrof 2014, mapy 7-9). Podobně v oblasti dnešního Brna byly vyčleněny jednotlivé mikroregiony s kontinuálním osídlením v mladší i pozdní době bronzové (Salaš 2011, 272). Čím se situace ve Vyškovské bráně odlišuje a proč došlo od pozdní doby bronzové k vyklizení podstatné části zemědělsky nejvýhodnějších terénů? 


\section{Diskuse}

Výrazné změny ve struktuře osídlení doby bronzové v oblasti Vyškovské brány je třeba nejen popsat, ale také navrhnout možné interpretace. Níže je v bodech komentováno několik okruhů možných vysvětlení.

- Výsledný obraz je hrubě zkreslen diky povaze archeologických pramenů a zpuisobu jejich ziskáni.

Archeologické prameny jednotlivých období se mohou projevovat zásadně odlišným způsobem, což ovlivňuje i „viditelnost“ jednotlivých komponent. Pouhá změna ve způsobu skladování obilí výrazně ovlivňuje archeologickou zachytitelnost sídelních komponent starší a střední doby bronzové na jižní Moravě (Parma 2015). Podobně podíl zdobené keramiky ovlivňuje možnost identifikovat př́slušné komponenty. Výrazný vliv může mít zvýšená mobilita sídelních areálů, produkující při rychlých posunech do nových lokací zdánlivě hustou sídelní sít.

Sídelní komponenty všech období se projevují zahloubenými objekty podobného typu, a to včetně lokalit pozdní doby bronzové, byt zde je evidence dosud silně sporadická (Parma - Holubová 2015). Sídelní areály mladší doby bronzové, jež byly ve větším rozsahu zkoumány, ukazují na dlouhodobé využívání téhož prostoru od časného po střední stupeň KPP (Ivanovice n. H. 6, 7; Parma - Šmíd 2013; Vyškov „Nouzka“, Parma a kol 2014). Podobně obsáhlejší nálezové kolekce pozdní doby bronzové z Habrovan „Vinohradů“, intravilánu Lulče a Drnovic „Niv“ ukazují na fungování komponent v mladším i pozdním stupni KPP (Parma - Holubová 2015), což ukazuje proti rychlé mobilitě sídelních komponent. Keramika pozdní doby bronzové je snáze identifikovatelná i v podobě velmi drobných zlomků díky charakteristické oběžné výzdobě, podíl takto datovaných lokalit by tedy měl být spíše nadhodnocen. Ze dvou nejvýraz- nějších zdrojů dat (sběry z okolí Drnovic, zkoumaná trasa dálnice) se artefakty pozdní doby bronzové objevují bez výjimky pouze v jediném, což lze vzhledem k rozsahu dat považovat za reprezentativní zjištění.

Pouze struktura archeologických pramenů nedokáže vysvětlit zásadní změnu sídelní sítě na počátku pozdní doby bronzové.

\section{- Na podobu sídelni sítè maji rozhodujici vliv cen- trálni lokality}

Ve sledovaném regionu se objevuje nejméně 7 výšinných lokalit, u nichž je možné počítat i s přítomností opevnění a tedy s funkcí odlišsnou od běžného sídelního areálu (Obr. 10, Tab. 4 - zde základní literatura; v soupisech a mapách na Obr. 8 a 9 se objevují pouze ty, u nichž je jasná př́ítomnost aktivit ze sledovaných užších horizontů). Základním problémem je ovšem nedostatek informací o přesném datování jejich využívání a o dataci případného opevnění. Lokalitou prvořadého významu je především rozsáhlá opevněná poloha Luleč 2 „Sv. Martin“ s odhadovaným rozsahem 55 ha. V mladší i pozdní době bronzové je hradiště bezprostředně obklopeno menším shlukem sídelních i jiných komponent (pocházejí odtud i jediné 4 depoty KPP z regionu; Salaš 2005, dep. č. 35, 43, 50, 51), výrazná je především polykulturní lokalita v centru obce Luleč s jednoznačnými nálezy ze střední, mladší i pozdní doby bronzové. Podrobná revize dostupných nálezů ovšem ukazuje, že ve stávajících fondech lze jen obtížně jednoznačně odlišit nálezy z obce a $\mathrm{z}$ vlastní plochy hradiště, jakkoliv podstatná část kolekce jehlic ze sbírky F. Travěnce, evidovaná J. Ř́hovským, nejspíše skutečně z plochy hradiště pochází (Ǩíhovský 1979). Drtivou většinu (15 z 22 jehlic; charakteristické typy stupně Ha B zcela chybí) z nich lze ovšem jasně datovat do mladší doby bronzové, podobně jako nepočetné zlomky keramiky s jasnou proveniencí a kamenný 


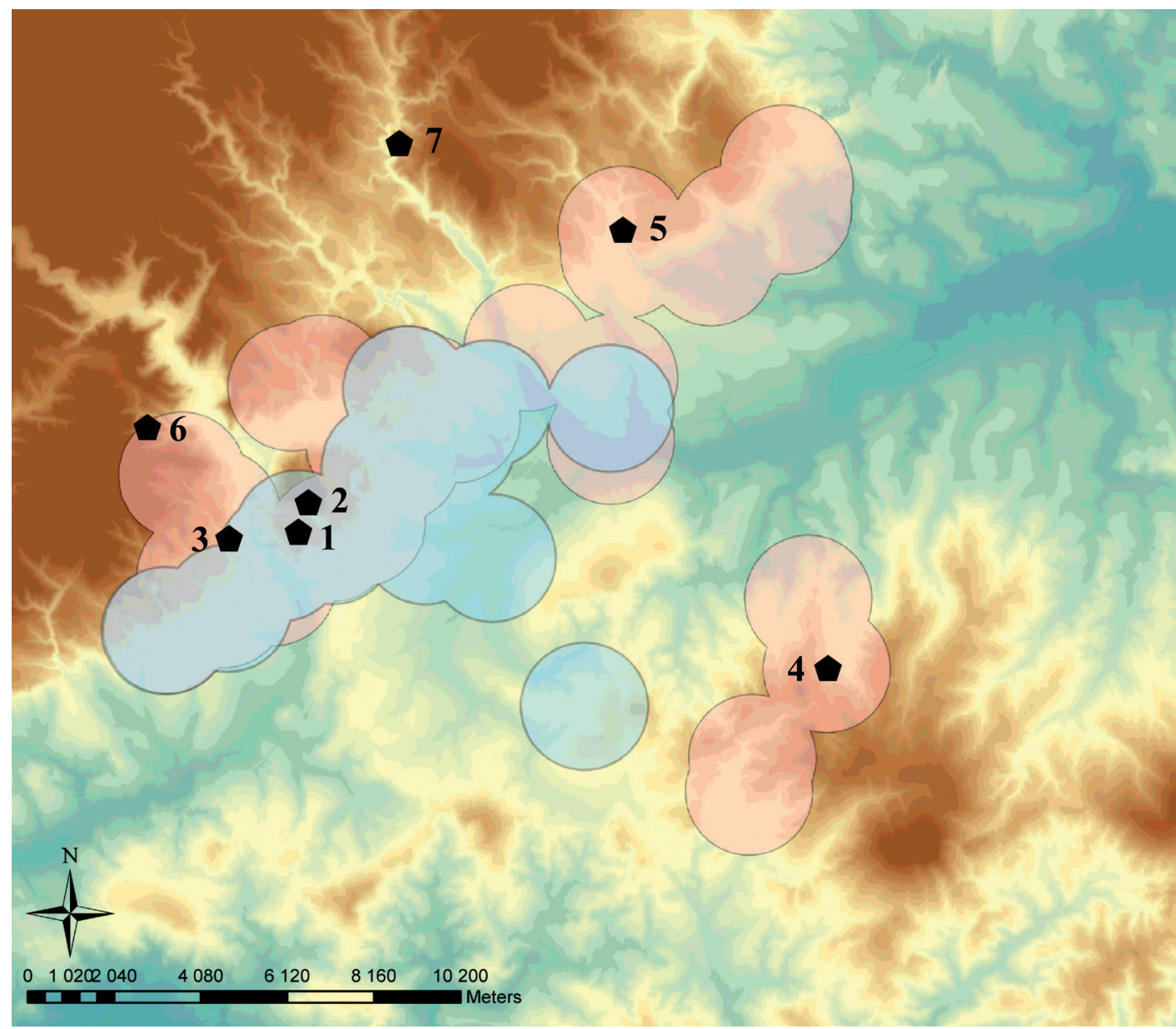

Obr. 10. Překryv obalových zón komponent pozdní doby bronzové a doby halštatské a sit' potenciálních opevněných a výšinných lokalit v prostoru Vyškovské brány: 1 - Luleč 2 "Sv. Martin”, 2 - Luleč 1 „Kolovratice”, 3 - Nemojany "Blatice”, 4 - Orlovice „Orlov", 5 - Radslavice „Zelená hora”, 6 - Račice "U Bílého kříže", 7 - Rychtářov "Valy”.

Fig. 10. Overlap of buffer zones of the Final Bronze Age and Early Iron Age components and a network of potential fortified and hilltop sites in the area of the Vyškov Gate: 1 - Luleč 2 "Sv. Martin”, 2 - Luleč 1 „Kolovratice”, 3 - Nemojany „Blatice", 4 - Orlovice "Orlov", 5 - Radslavice "Zelená hora”, 6 - Račice "U Bílého křriže", 7 - Rychtářov "Valy".

kadlub k odlévání jehlic ze sbírek Muzea Vyš- mladší i pozdní doby bronzové, byla by plně kovska (lokalitě bude věnována bližší pozornost srovnatelná s rozsáhlými centrálními hradišti samostatně). Jediným jednoznačným dokladem jako Brno-Obřany či Stillfried. V každém př́ípaaktivit pozdní doby bronzové je tak depot Luleč dě by bylo možné předpokládat, že právě opev2 (Salaš 2005, 441-442). Řešením těchto otázek něné sídliště na „Sv. Martinu“ mohlo mít vliv bude patrně získání dostatečně početné kolekce na podobu osídlení Vyškovské brány v pozdjasně lokalizovaných nových nálezů, na jejichž ní době bronzové, nebot’ se nachází prakticky základě bude možné upřesnit interval osídle- uprostřed jediného shluku takto datovaných ní polohy. Pokud by šlo o opevněnou lokalitu komponent. Hypoteticky se nabízí i možnost, 


\begin{tabular}{|c|l|l|l|l|}
\hline ID_mapa & \multicolumn{1}{|c|}{ Katastr } & \multicolumn{1}{c|}{ Poloha } & \multicolumn{1}{c|}{ Datace } & \multicolumn{1}{c|}{ Literatura } \\
\hline 1 & Luleč 2 & Sv. Martin & br.m-p & Čižmář 2004, 172-173 \\
\hline 2 & Luleč 1 & Kolovratice & $?$ & Čižmář 2004, 171-172 \\
\hline 3 & Nemojany & Blatice & lengye, halsta & Čižmář 2004, 189-190 \\
\hline 4 & Orlovice & Orlov & halsta? & Čižmář 2004, 196-197 \\
\hline 5 & Radslavice & Zelená hora & ha.d & Holubová 2008 \\
\hline 6 & Račice & U Bílého kříže & br.m-p? & Čižmář 2004, 219-220 \\
\hline 7 & Rychtářov & Valy & eneoli, br.po & Čižmář 2004, 225-226 \\
\hline
\end{tabular}

Tab. 4. Výšinné a opevněné lokality v širším prostoru Vyškovské brány.

Tab. 4. Fortified and hilltop sites in a wider area of the Vyškov Gate.

že za změnou struktury osídlení v tomto horizontu může stát především změna významu a funkce hradiska Luleč 2 . Nelze např. vyloučit, že rozsáhlé obvodové opevnění je novostavbou z pozdní doby bronzové, výrazně rozšiřující rozsah staršího hradiště, analogicky situaci na Leskounu u Olbramovic (Fojtík - Parma 2013, 70; v prrípadě sv. Martina je menší vnitřní opevnění dobře patrné na starších i nejnovějších plánech i v parcelaci vrcholové plošiny; Čižmář 2004, 172-173).

Další opevněné polohy v regionu jsou výrazně menšího rozsahu. Nejméně problematické je datování početných nálezů z polohy Radslavice „Zelená hora“ do mladší doby halštatské (Ha D2; Holubová 2008), nálezy jen rámcově z doby halštatské pocházejí i z drobného opevnění Nemojany „Blatice“ a z výšinné polohy hradu Orlov v Orlovicích. Z výrazného opevnění v poloze Luleč 1 „Kolovratice“ o rozsahu 3,4 ha pochází jen nálezy rámcově pravěkého stáří, stejně obtížně datovatelný je dostupný materiál z velmi podobné polohy Rychtářov „Valy“1 a méně výrazného opevnění Račice „U bílého křiže“. Rozložení trojice lokalit s doloženými aktivitami doby halštatské (Radslavice - Nemojany - Orlovice) dobře odpovídá trojici shluků rámcově současných komponent, ovšem jejich lákavé ztotožnění s centrálními lokalitami, kolem nichž se koncentruje celá soudobá sídelní aktivita, je zatím spíše volnou hypotézou. Především ani $\mathrm{v}$ jednom případě není datováno opevnění (v Orlovicích i Radslavicích je zničeno středověkými hrady) a disproporce panují i relativní chronologii - Radslavice, jasně datované do stupně Ha D2, se nacházejí uprostřed shluku lokalit s mnohem širší datací (Baarová 2007; Holubová 2008).

Opevněné výšinné lokality včetně případných center prvního řádu (Luleč 2) mohly významným způsobem formovat sídelní sít již od mladší doby bronzové, ovšem jasným limitujícím faktorem je nedostatek dat o jejich chronologii a funkci.

- Na podobu sídelni sitě má vliv změna subsistenčni strategie, reagujici př́padně na změnu vnějšich podminek

Radikální změna subsistenční strategie, jako je odlišné spektrum pěstovaných plodin a zemědělských postupů nebo posun k pastevecké ekonomice, může být reakcí na vnitřní procesy působící ve společenstvech nebo na změnu vnějších podmínek (přírodních - změna klimatu, společenských - etnické posuny).

Starší koncepce počítající s obecnou změnou klimatu na přechodu biostratografických zón epiatlantiku a subboreálu, tedy přibližně v průběhu pozdní doby bronzové, počítají obvykle i možné 
posuny v zemědělských strategiích směrem k vyššímu podílu pastevectví (např. Bouzek 2005; ke členění přehledně Kuna ed. 2007, Obr. 9). Oproti tomu jiné modely ukazují na spíše regionalizovaný vývoj, v němž hrají globální trendy vedlejší roli; Brysonův makroklimatický fyzikální model ukazuje na základě dat z Ivanovic na Hané nejnižší teploty ve střední době bronzové, jejich vzestup a poté výrazný pokles od počátku pozdní doby bronzové, na počátku mladší a poté zejména v průběhu pozdní doby bronzové dochází k nárůstu srážek (data zpracovala M. Hajnalová a budou publikována na jiném místě; $\mathrm{k}$ metodě Hajnalová 2012, 4-8).

Přímá data ovšem nenasvědčují radikální proměně ekonomiky - ve všech sledovaných úsecích jsou běžným typem zahloubených objektů sila, v př́padě kontinuálně osídlené oblasti v okolí Lulče je patrná stálá vazba na vodní zdroje a využívání stejných poloh. Pramenů pro rekonstrukci hospodářských strategií je dosud jen minimum, ani ty ovšem nenaznačují radikální změny - pro kulturně příbuznou slovenskou oblast se v pozdní době bronzové počítá s kontinuitou sortimentu pěstovaných plodin a posunem spíše k extenzivním metodám využívajícím větší rozlohy polí (Hajnalová 2012, 153-156).

Pro posouzení vnějších vlivů v podobě klimatu a s ním spojených změn subsistenčních strategií chybí z regionu přímá data, především zpracované soubory ekofaktů ze sídelních areálů, chybí i evidence změn v krajině v podobě pylových profilů. Přesto je nepravděpodobné, že by na přelomu mladší a pozdní doby bronzové došlo k natolik radikální změně, která by objasňovala proměnu sídelní sítě.

- Podoba regionálni sídelni sitě odráži události a změny na úrowni vyššich organizačnich celků společnosti

Proměna sídelní sítě může být vedle vnějších faktorů způsobena vnitřními sociálními proce- sy - změnami v podobě a rozsahu základních organizačních jednotek společnosti. Tento faktor je ve sledovaném regionu významný zvláště pokud vezmeme v potaz jeho polohu na rozhraní základních archeologických kulturních skupin, středodunajské na jihu a lužické na severu. Archeologické kultury jsou tradičně ve středoevropském prostředí vnímány jako primární interpretační východisko, což ovšem do značné míry neodpovídá struktuře pramenů. Na úrovni základní deskripce a klasifikace je ovšem rozdílný charakter hmotné kultury střední a jižní Moravy neoddiskutovatelný a jasně se projevuje i v souborech z Vyškovské brány. Zjednodušeně lze říci, že hmotná kultura mladší doby bronzové zřetelně inklinuje ke středodunajskému kulturnímu prostředí, zatímco v pozdní době bronzové dochází k razantní změně směrem k prostředí lužickému. Tento rozdíl je vyhraněný především v souborech sídlištní keramiky, v př́ípadě keramiky funerální a šperku jsou rozdíly mnohem menší (Parma v tisku).

Pokud budeme v duchu kulturně-typologického paradigmatu uvažovat o ztotožnění archeologických kultur s původními společenskými jednotkami a etniky, můžeme situaci ve Vyškovské bráně interpretovat jako ukázkový posun kulturních hranice a nahrazení původního osídlení etnicky odlišnou populací se zcela novou sídelní strukturou. Stejná změna hmotné kultury v severní části Brněnské kotliny se ovšem žádnou výraznou změnou sídelní sítě neprojevuje (Salaš 2011, 312) a k obecnému rozšíření keramiky zdobené „slezským“ stylem dochází v daleko větším geografickém měřítku, na což bylo opakovaně upozorňováno (např. Podborský a kol. 1993, 310). Rovněž v okolí možné centrální lokality na sv. Martinu u Lulče, stejně jako přímo v opevněném prostoru, evidujeme spíše kontinuální osídlení. Sídelní sít v podobě výrazně oddělených shluků není ani pro středomoravskou lužickou oblast přiliš typická (Vránová 2013). Hypoteticky můžeme také předpokládat, 
že se výrazně mění celá společenská struktura i velikost základních organizačních jednotek směrem k centralizaci, což by se mohlo projevovat výrazněji právě v kontaktní oblasti velkých etnických okruhů. Další možností je vyklizení přirozeného komunikačního prostoru v nížině kolem Hané v reakci na jiný vnější společenský faktor - př́tomnost mobilních bojovnických skupin v návaznosti na šíření nomádských kulturních okruhů z Černomoří do Karpatské kotliny. Zde je ovšem problémem značná časová disproporce - ke změně sídelních struktur dochází evidentně na počátku stupně $\mathrm{Ha} \mathrm{B}$, zatímco nomádská hmotná kultura se šírí až v jeho závěru (9.-8. stol.; Metzner-Nebelsick 2010).

Interpretace založené na etnických posunech a změnách organizace společnosti jsou lákavé, ovšem zatím jen obtížně testovatelné v archeologických datech. Značná část tezí zde přímo vychází z metodických předpokladů kulturně historického paradigmatu, které jsou samy o sobě problematické a nevysvětlují strukturu pramenů nejlepším možným způsobem.

\section{Závěr}

Dosavadní představy o podobě sídelní sítě v době bronzové předpokládaly spíše model stabilního a rovnoměrného využití krajiny ve staré sídelní zóně. Výsledky rozsáhlého záchranného výzkumu v liniové stavbě dálnice Brno - Kroměříž ${ }^{2}$ ovšem ukázaly, že zastoupení komponent mladšího pravěku je velmi nerovnoměrné. Množství zachycených lokalit střední a mladší doby bronzové je v nepoměru s (téměř) úplnou absencí aktivit z pozdní doby bronzové a doby halštatské. Na př́kladu ukázkového regionu Vyškovské brány s velkým množstvím zpracovaných a publikovaných dat se prokázalo, že po kritickém vymapování osídlení jednotlivých chronologických úseků se zde komponenty pozdní doby bronzové i doby halštatské vyskytují, nacházejí se ovšem zcela mimo trasu dálnice. Zatímco ve střední a mladší době bronzové je region pokryt rovnoměrnou sítí osídlení, od pozdní doby bronzové jsou aktivity zachytitelné pouze v jeho menší části a tvoří prostorově uzavřený shluk kolem možné centrální opevněné lokality. Podobně v době halštatské se osídlení koncentruje v okrajových zónách na svazích vrchovin ve třech oddělených shlucích a centrální sníženina zůstává prakticky beze stop aktivity. Vzhledem $\mathrm{k}$ reprezentativnosti dat tento stav není pouhým artefaktem daným stavem poznání či strukturou archeologických pramenů, stejně jako patrně nejde o důsledek radikální změny subsistenčních strategií v reakci na př́ípadné změny klimatu. Vysvětlení musíme hledat patrně ve změnách ve společnosti samé, at již jde o proces centralizace projevující se nástupem opevněných poloh a přilehlých aglomerací s nadregionálními funkcemi, nebo o důsledky rozsáhlých etnických posunů. Region Vyškovské brány je díky dobré datové základně zvláště vhodný pro testování těchto hypotéz, po formulaci konkrétních otázek zde lze nepochybně v budoucnu získat příslušná nová data a následně i velmi konkrétní odpovědi. Zároveň lze pak tímto způsobem i testovat základní paradigmata a metodická východiska moravské archeologie.

\section{Poznámky:}

1) V roce 2016 zde byla získána kolekce nálezů z časného a středního eneolitu a pozdní doby bronzové.

2) Katastry zahrnuté do studie: Bohdalice, Boškůvky, Dědice, Drnovice, Drysice, Habrovany, Heroltice, Hlubočany, Hoštice, Ivanovice na Hané, Kučerov, Luleč, Lysovice, Manerov, Medlovice, Moravské Málkovice, Moravké Prusy, Nemojany, Opatovice, Pístovice, Pustiměř, Pustiměřské Prusy, Račice, Tučapy, Radslavice, Rostěnice, Rybníček, Terešov, Topolany, Vážany, Vyškov, Zelená hora, Zouvalka, Zvonovice. 


\section{Literatura}

Baarová, Z. 2007: Platěnické pohřebiště s komorovými hroby v Pustiměři. In: Doba popelnicových polí a doba halštatská. Příspěvky z IX. konference, Bučovice 3.-6. 10. 2006, Brno, 13-33.

Baarová, Z. - Mikulková, B. 2006: Halštatské žárové pohřebiště v Drnovicích (okr. Vyškov), Pravěk NŘ 14/2004, 287-331.

Beneš, Z. 2007: Sídliště z pozdní doby římské v Mořicích (okr. Prostějov), in: Droberjar, E. - Chvojka, O. (edd), Archeologie barbarů 2006. Sborník příspěvků z II. protohistorické konference, České Budějovice 21.-24. 11. 2006, Archeologické výzkumy v jžních Čechách Supplementum III, České Budějovice, 473-506.

Bouzek, J. 2005: Klimatické změny ve středoevropském pravěku, Archeologické rozhledy LVII, 493-528.

Čižmář, M. 1985: Laténské pohřebiště v Bedřichovicích, Archeologické rozhledy XXXVII, 442-445.

Čižmář, M. 2004: Encyklopedie hradišṫ na Moravě a ve Slezsku, Praha.

Čižmář, M. - Dvořák, P. 1985: Protoúnětické pohřebiště v Bedřichovicích, Archeologické rozhledy XXXVII, 413-425.

Čižmář, M. - Geisler, M. 1998: Hroby kultury se šňůrovou keramikou z prostoru dálnice Brno - Vyškov, Pravěk Supplementum 1, Brno.

Čižmář, Z. - Geislerová, K. 1997: Sídliště kultury s lineární keramikou ve Slavíkovicích, okr. Vyškov, Pravěk NŘ 6/1996, 51-74.

Daňhel, M. - Pankowská, A. 2008: Věteřovské sídliště v Křenovicích - „Padělcích od Dřínového“. In: Bém, M. - Peška, J. (eds.), Ročenka 2007, Olomouc, 72-97.

Demek, J. - Mackovčin, P. (eds.) 2006: Hory a nížiny. Zeměpisný lexikon ČR, Brno.

Fojtík, P. - Parma, D. 2014: Doba bronzová. In: Geislerová, K. - Parma, D. eds., Výzkumy - Ausgrabungen 2005-2010, Brno, 52-71.

Geisler, M. 1985: Slovanské hroby z Holubic V, okr. Vyškov, Archeologické rozhledy XXXVII, 449453.

Geisler, M. 1992: Statistické zhodnocení mladohradištního pohřebiště z Holubic, okr. Vyškov, Pravěk NŘ 2/1992, 359-370.
Geislerová, K. 1985: Sídliště kultury s lineární keramikou v Holubicích, Archeologické rozhledy XXXVII, 368-373.

Geislerová, K. - Janák, V. 1985: Drysice, okr. Vyškov. Sídliště kultury lineární a velatické. NZ č. 607/85 v archivu AÚ Brno.

Hajnalová, M. 2012: Archeobotanika doby bronzovej na Slovensku, Nitra.

Holubová, Z. 2008: Osídlení hradiska Zelená hora v době halštatské, Pravěk NŘ 17/2007, 357-382.

Horálková, P. 1993: Pozdně laténské sídliště ve Vyškově s nálezy germánské keramiky, Archeologické rozhledy ILV, 474-491.

Jiráň, L. a kol. 2008: Archeologie pravěkých Čech 5. Doba bronzová, Praha.

Kolář, J. a kol. 2011: Kultura se šňůrovou keramikou v povodí ŕíčky Hané na střední Moravě. Pohřební areály z prostoru dálnice D1 v úseku Vyškov - Mořice a dalších staveb, Pravěk Supplementum 23, Brno.

Kuna, M. ed. 2007: Pravěký svět a jeho poznání. Archeologie pravěkých Čech 1, Praha.

Matějíčková, A. - Dvořák, P. (eds.) 2012: Pohřebišš z období zvoncovitých pohárů na trase dálnice D1 Vyškov - Mořice, Pravěk Supplementum 24, Brno.

Metzner-Nebelsick, C. 2010: Aspects of mobility and migration in the eastern Carpatian Basin and adjacent areas in the early Iron Age (10th-7th centuries BC). In: Dziȩgelewski, K. - Przybyła, M. Gawlik, A. (eds.): Migration in Bronze and Early Iron Age Europe, Prace Archaeologiczne 63, Kraków, 121-151.

Mikulková, B. 2013: Kučerov - Nivy 2012. Rozšíření SV Vyškov - III. etapa. NZ č. 391/13 v archivu ÚAPP Brno.

Nekvasil, J. 1970: Konečný vývojový stupeň stř̌edního (slezského) období lužické kultury na Moravě, Památky archeologické LXI, 15-99.

Parma, D. 2007: Pohřebiště Hoštice 4 (okr. Vyškov). Př́́spěvek k poznání variability pohřebního ritu v mladší době bronzové. In: Doba popelnicových polí a doba halštatská. Příspěvky z IX. konference, Bučovice 3.-6. 10. 2006, Brno, 177-204.

Parma, D. 2011: Sídelní areály střední a mladší doby bronzové z trasy dálnice D 1 u Vyškova. Katalog část 1, Pravěk Supplementum 22, Brno. 
Parma, D. 2015: Poznámky k sídelním strukturám starší a střední doby bronzové na jižní Moravě, in: Bátora, J. - Tóth, P. eds.: Ked' bronz vystriedal med', Bratislava - Nitra 2015, 243-260.

Parma v tisku: Archeologické kultury - koncepce a praxe. In: Juchelka, J. ed: Doba popelnicových polí a doba halštatská ve střední Evropě 2. díl, Opava - Brno.

Parma, D. - Holubová Z. 2015: Záchranné výzkumy v Habrovanech a otázka pozdně bronzového osídlení Vyškovské brány, Pravěk NŘ 23, 99-148.

Parma, D. - Mikulková, B. - Šmíd, M. - Nohálová, H. 2015: Sídelní areály střední doby bronzové v Drnovicích u Vyškova. SbSNM - Archeológia 25, 37-72.

Parma, D. - Šmíd, M. 2013: Sídelní areály střední a mladší doby bronzové z trasy dálnice D 1 u Vyškova. Katalog - část 2, Pravěk Supplementum 26, Brno.

Parma, D. - Kala, J. - Mikulková, B. - Nývltová Fišáková, M. 2014: Sídelní areály doby bronzové Vyškov „Nouzka“. Výsledky výzkumů z let 2007-2010, Pravěk Ň̌ 22, 45-104.

Peška, J. - Tajer, A. 2006: První kostrový hrob jevišovické kultury na Moravě? In: Bém, M. - Peška, J. (eds.), Ročenka 2005, Olomouc, 35-52.

Peška, J. - Tajer, A. 2007: Hrob kultury zvoncovitých pohárů s nadzemní konstrukcí a zlatem ze Stříbrnic. In: Bém, M. - Peška, J. (eds.), Ročenka 2006, Olomouc, 67-87.

Peška, J. - Tajer, A. 2009: Přríspěvek k poznání jevišovického osídlení na střední Moravě. In: Bém, M. Peška, J. (eds.), Ročenka 2008, Olomouc, 59-107.

Podborský, V. a kol. 1993: Pravěké dějiny Moravy, Brno.

Primas, M. 2008: Bronzezeit zwischen Elbe und Po. Strukturwandel in Zentraleuropa 2200-800 v. Chr., UPA 150, Bonn.

Rakovský, I. 1985a: Sídliště kultury zvoncovitých pohárů v Holubicích, Archeologické rozhledy XXXVII, 377-392.

Rakovský, I. 1985b: Pohřebiště kultury zvoncovitých pohárů v Holubicích, Archeologické rozhledy XXXVII, 393-400.
Rakovský, I. 1985c: Sídlištní jáma kultury s moravskou malovanou keramikou u Tvarožné, Archeologické rozhledy XXXVII, 441-442.

Roberts, B. W. - Uckelmann, M. - Brandherm, D. 2013: Old father time: the Bronze Age chronology of western Europe. In: Fokkens, H. - Harding, A. eds.: The Oxford handbook of the european Bronze Age, Oxford, 17-46.

Říhovský, J. 1960: K otázce pronikání lidu s velatickou kulturou k severu. In: Sborník AÚ ČSAV Brno I, Brno, 45-49.

Ř́hovský, J: 1979: Die Nadeln in Mähren und im Ostalpengebiet, PBF XIII/5, München.

Salaš, M. 2005: Bronzové depoty střední až pozdní doby bronzové na Moravě a ve Slezsku, Brno.

Salaš, M. 2011: Společnost organizované moci v mladší a pozdní době bronzové. In: Procházka, R. ed.: Dějiny Brna 1. Od pravěku k ranému středověku, Brno, 268-318.

Sklenářová, Z. - Krušinová, L. - Baštová, D. - Volfík, P. 1996: Státní archeologický seznam ČR, uživatelská příručka, Praha.

Šedo, O. 1985: Chata z doby římské v Holubicích, okr. Vyškov, Archeologické rozhledy XXXVII, 446-449.

Štrof, A. 2014: Doba bronzová a starší doba železná / halštatská. In: Jarůšková, Z. - Štrof, A. (eds): Pravěk Boskovicka. Vlastivěda Boskovicka sv. 3, Boskovice, 101-178.

Tajer, A. 2007: Lidské pohřby v jamách věteřovského sídliště na lokalitě Vrchoslavice - Vitčice 1. In: Bém, M. - Peška, J. (eds.), Ročenka 2006, Olomouc, 88-103.

Tajer, A. - Vránová, V. 2011: Halštatská sídelní struktura na př́íkladu sídliště v Křenovicích. In: Doba popelnicových polí a doba halštatská. Příspěvky z XI. konference, Příbram 7.-10. září 2010, Příbram, 157-171.

Trňáčková, Z. 1957: Lužické žárové hroby ze Švábenic na Moravě, Archeologické rozhledy IX, 609-611.

Vránová, V. 2013: Struktura osídlení v období popelnicových polí na střední Moravě. ARF 12, Olomouc. 


\section{Resume}

Earlier knowledge of the appearance of the Bronze Age settlement network rather supposed a model of stable and balanced landscape use in the old settlement area. But the results of an extensive rescue excavation in the linear construction of the BrnoKroměŕíz motorway showed that the proportion of components from later prehistory is very imbalanced. The number of Middle and Late Bronze Age localities identified is not proportional to (almost) complete absence of activities of the Final Bronze Age and the Hallstatt Period. The example of a selected region of the Vyškov Gate with many processed and published data has clearly showed that a critical mapping of settlement in individual chronological periods revealed the existence of components of the Final Bronze Age and the Hallstatt Period which, however, are situated completely out of the motorway route. While in the Middle and Late Bronze Age the region is covered with a regular settlement network, from the Final Bronze Age onward these activities are only identifiable in its minor part where they form a closed cluster around the presumed central fortified site. Similarly, the Hallstatt Period settlement is concentrated on hillsides in peripheral zones in three separate clusters, while the central depression exhibits as good as no traces of any settlement activity. Regarding the representativeness of data, this condition is not given by merely the state of knowledge or the structure of archaeological sources, and it is probably not caused by any radical change of subsistence strategies in reaction to possible climate changes, either. The explanation must probably be sought in the changes of society, whether it is a centralisation process reflected in the onset of extensive fortified agglomerations with trans-regional functions, or the effects of extensive ethnic movements. The Vyškov Gate region, due to its good source base, is particularly suitable for testing these hypotheses. After formulation of specific questions in the future it will undoubtedly be possible to obtain new data and subsequently very detailed answers as well. In this way it is also possible to test the fundamental paradigms and methodological bases of the Moravian archaeology. 
Mgr. David Parma, Ph.D.

- Ústav archeologické památkové péče Brno, v.v.i Kaloudova 30, 61400 Brno, parma@uapp.cz

\section{Mgr. Zuzana Holubová}

- Muzeum města Brna,

Špilberk 210/1, 66224 Brno, holubova@spilberk.cz

\section{Mgr. Klára Rybářová}

- Muzeum Vyškovska, Nám. Čs. Armády 475/2, 68201 Vyškov, rybarova@muzeum-vyskovska.cz 